\title{
Shamanism, Globalisation and Religion in the Contemporary Art of Said Atabekov and the Kazakh Art Collective Kyzyl Tractor
}

\author{
Emina Yessekeyeva ${ }^{1,2, *}$ and Eric Venbrux ${ }^{2}$ (D) \\ 1 Department of Religious and Cultural Studies, Faculty of Philosophy and Political Science, Al-Farabi Kazakh \\ National University, Almaty 050040, Kazakhstan \\ 2 Department of Comparative Religion, Faculty of Philosophy, Theology and Religious Studies, Radboud \\ University, Erasmusplein 1, 6525 HT Nijmegen, The Netherlands; e.venbrux@ftr.ru.nl \\ * Correspondence: e.yessekeyeva@ftr.ru.nl or aminayesekeyeva@gmail.com
}

check for updates

Citation: Yessekeyeva, Emina, and Eric Venbrux. 2021. Shamanism, Globalisation and Religion in the Contemporary Art of Said Atabekov and the Kazakh Art Collective Kyzyl Tractor. Religions 12: 300. https://doi.org/10.3390/ rel12050300

Academic Editors: Klaus Baumann and Thomas Michael

Received: 15 February 2021

Accepted: 21 April 2021

Published: 24 April 2021

Publisher's Note: MDPI stays neutral with regard to jurisdictional claims in published maps and institutional affiliations.

Copyright: (c) 2021 by the authors. Licensee MDPI, Basel, Switzerland. This article is an open access article distributed under the terms and conditions of the Creative Commons Attribution (CC BY) license (https:/ / creativecommons.org/licenses/by/ $4.0 /)$.

\begin{abstract}
Central Asia's most famous artist Said Atabekov both interrogates and imagines religiosity in post-Soviet Kazakhstan in his art. He has been doing so as a member of the Kyzyl Tractor (Red Tractor) art collective and in his own art practice. They perform as shamans and explore the nomadic steppe culture of the days of yore. Offering a nuanced and often ironic critique of present-day developments in his art, Atabekov seeks to make his audience think about meaning making or the lack thereof. He highlights the inclusiveness of vernacular religion while simultaneously drawing attention to the vacuousness of the hegemonic ideologies of the day, ranging from communism to capitalism to dogmatic religion. From his oeuvre, we discuss works that concern a dervish shaman, the nomadic game of kokpar and the advent of rigid religion, respectively.
\end{abstract}

Keywords: Said Atabekov; Kyzyl Tractor; contemporary art; Shamanism; Tengrism; Sufism; Kazakhstan

\section{Introduction}

Sometimes enacting the role of a shaman, Said Atabekov (born in 1965) both interrogates and imagines religiosity in post-Soviet Kazakhstan in his art. He has been doing so as a member of the Kyzyl Tractor (Red Tractor) art collective and in his own art practice. Atabekov lives and works in Shymkent, South Kazakhstan. Internationally, he is one of the most well-known contemporary artists from Central Asia. The artist himself asserts that he is more famous abroad than in Kazakhstan. Atabekov seeks to make his audience think about meaning making or the lack thereof. He explores cultural heritage and vernacular religion while simultaneously drawing attention to the vacuousness of the hegemonic ideologies of the day, ranging from communism to capitalism to dogmatic religion. Atabekov said in an interview with the first author that he follows three themes: 'culture-religionpolitics ${ }^{\prime 1}$. In this article, we look at his engagement with religion in his artwork over the course of his career. Atabekov's career as an artist began with the Kyzyl Tractor collective. It entailed an experience that in many ways was formative, not in the least because the group's creativity, due to the collapse of the Soviet Union, broke new ground in critically examining the possibilities for the formation of a new Kazakhstani identity.

In the Soviet era, practicing a religion such as Islam was seen as backward, but 'the practices of shamanism and other pre-Islamic belief systems were considered even more backward, and their practitioners blacklisted as charlatans and cheats' (Adams 2020, p. 165; cf. Znamenski 2003, p. 23). Atabekov and his fellow artists took a different approach. In the mid-1990s, the members of Kyzyl Tractor dressed up as shamans and went on a spiritual trip. They slept in the steppe. In the words of Atabekov: 'We imagined ourselves as ancient shamans. We tried to reconnect with the steppe and with the cultural heritage' (Kudaibergenova 2019, p. 233). He refers to the nomadic culture of olden times on the 
steppe in Central Asia (cf. Atanova 2020). In 1998, Atabekov performed in the outfit of a dervish shaman on a prayer rug consisting of stones at an art venue in Almaty. Kudaibergenova $(2019$, p. 232) notes that ' $[\mathrm{t}]$ his performance became one of the most iconic artistic works in the history of post-Soviet contemporary art in the region.' We will discuss it further below (see also Figure 5). 'Shamanism, Tengriism and Islam coexisted peacefully in the syncretic consciousness of the Kazakh nomadic culture,' according to Syzdykova (Syzdykova 2017, p. 104; see also Laruelle 2006 and Vuillemenot 2013). Moreover, Atabekov and the Kyzyl Tractor collective, of which he is a founding member, take inspiration from folk religion. They have performed as shamans on numerous occasions in Kazakhstan, as well as abroad. In doing so, they and other artists not only raise the question 'what does it mean to be post-Soviet' (Tlostanova 2018), but they also offer a stinging critique of the spiritual void of the state's development programme, the encroachment of capitalism and globalised consumerism. It is their badge of honour to remain independent of the state. The avant-garde artists of Kyzyl Tractor have also rolled oil barrels down the central boulevard of Almaty in the attire of shamans. They have thus called into question the blessings of Kazakhstan's main resource (exploited by American companies) and source of unequally divided wealth (Kudaibergenova 2019, pp. 233-34). Of the individual artists, writes Kudaibergenova (2019, p. 234), 'Said Atabekov's effort to connect distorted and disjointed spiritual and cultural elements has been particularly strong.' With regard to his shamanistic performances, Abatekov has also been influenced by Kazakh artist Rushtam Kahlfin (1949-2008), who in turn was influenced by Joseph Beuys' artistic shamanism (Sorokina and Shklyayeva 2016, pp. 518-19, 525). Therewith, he stands as it were in a tradition of contemporary artists acting as shamans (for other examples of such artists, see Doyon-Bernard 1997; Ingels 2004; Walters 2010; Milledge 2013; Thackara 2017). An early representative is avant-garde artist Vasilii Kandinsky, who was strongly inspired by shamanism (see Weiss 1995; Znamenski 2003, p. 20).

The relationship between shamanism and art, contemporary as well as in a distant past, has been given considerable attention (see Wallis 2019; Djaltchinova-Malec 2014). Wallis (2019) notes that the term shamanism has been 'used so loosely that it can refer to almost any ritual specialist and almost any form of artistic inspiration.' Together with Siberia, Central Asia, however, is the locus classicus of shamanism (Eliade [1951] 1989). Yet, DeWeese (2014) makes clear that a form of 'shamanization' also took place here:

Soviet ethnographic scholarship relegated a host of phenomena with clear roots in Sufi practice to the sphere of "shamanism" and interpreted their continued practice, in Soviet times, as examples of "survivals" (perezhitki) of pre-Islamic rituals (since "shamanism" itself was understood to be an earlier form of religion, historically prior to Islam, rather than a mode of religiosity that might be manifested in various religious contexts).

'Shamanism is not a religion as such, but a cosmological complex of beliefs, myths, rituals, practices and paraphernalia centred on the person of the shaman' (Bowie 2006, p. 181). The crux is that a shaman is a bricoleur, an 'innovator' (Handelman 1967). Balikci (1963), who studied shamanism amongst the Inuit, accords great importance to meaning making. He found 'the shaman the integrator of many religious conceptions' (Balikci 1963). What is more, Balikci (1963) draws attention to 'the relationship between the shaman, as an individual, and the group,' particularly the ways in which the shaman is affecting the social life in times of crises. He concludes: 'In his role as integrator, in a stream of symbolic effusions, the shaman gave new meanings to a multiplicity of situations which would have remained inexplicable to society without his intervention' (Balikci 1963, p. 395). This fits with the Kazakh contemporary artists, that is the avant-garde in the post-Soviet era, particularly Said Atabekov. Above, Kudaibergenova (2019, p. 34) praises him for being such an integrator or connector of multiple religious conceptions. Furthermore, she points out that the avant-garde artists' joint focus is on Tengrism, the undogmatic, nomadic folk religion, whereas the representations of shamans vary, and that this 'offers unlimited space for artistic freedom and self-expression' (ibid., p. 337). 
Atabekov, the artist, is what Gell (Gell 1998, pp. 44-53) would call 'an occult technician', who makes use of 'the technology of enchantment'. In this, he resembles a shaman (cf. Misiano 2011; Humphrey 1999). Following Milledge (2013, p. 5), 'the artist-shaman plays a mediatory, transitory and transformative role, in between the visible and the invisible. That is, the artist-shaman does not merely imitate something that can already be seen, he or she makes visible something that does not already exist visibly.' Said Atabekov clearly follows this path. Before we turn to his artwork and career, we will discuss the Kyzyl Tractor art movement of which Said Atabekov is a prominent member with respect to the quest for identity following the dissolution of the Soviet Union. Thereafter, we discuss Atabekov's work as an individual artist and 'modern shaman', followed by a section on his subsequent work relating to the kokpar game, nomadic cultural and religious practices in a globalised world. The subsequent works of art we discuss deal with the emergence of official, fundamentalist religion, contrasted with the imaginary steppe and its role in society. Finally, we will draw our conclusions.

\section{The Post-Soviet Art Collective Kyzyl Tractor: Modern Nomads of the Steppe}

The territory of present-day Kazakhstan was the domain of a nomadic steppe culture for several millennia. In the thirteenth century, it became part of the Mongol Empire under Genghis Kahn. Two centuries later, a distinct Kazakh identity emerged in the Kazakh War of Independence. During the course of the eighteenth and nineteenth centuries, however, Kazakhstan was subjugated by the expanding Russian Empire. After the Russian Revolution in 1917, it was not until 1936 that the territory became the Kazakh Soviet Socialist Republic. Stalin's first Five-Year Plan in 1929 brought enforced collectivisation and sedentarisation and, therewith, sounded the death knell for the nomadic way of life. The plan to produce an abundance of grain and meat on large state farms failed for a number of reasons. A drought worsened the situation. In the early 1930s, onequarter of Kazakhstan's population, that is, about 1.5 million people, starved to death (Cameron 2018; Kindler 2018). It took decades for society to recover, while repression was a mainstay. Not surprisingly, there was also 'a feeling of disappointment by the failure of the Soviet state to fully deliver its promised goals' (Dave 2007, p. 2). Remarkably, there happened to be a scarcity of tractors in the republic (Cameron 2018, p. 154). The tractor, that epitome of modernisation (Figure 1), would become the emblem of one of the country's first art movements in the post-Soviet era.

The Republic of Kazakhstan declared its independence on 16 December 1991, shortly before the Soviet Union (USSR) collapsed. Kazakhstan opened up to the world, especially the capitalist world, and allowed for greater artistic freedom. The censorship (and its corollary of self-censorship) that had characterised Soviet dealings with the arts since 'socialist realism' became the dogma in the early 1930s (Wallach 1991) was no more. The same accounts for the repression of religion (see Dragadze 1993). Some artists continued the pattern of portraying powerholders as in the days of art clientelism (Nauruzbayeva 2011), but as mentioned, the Kazakhstani post-Soviet avant-garde artists did and had to do without state support. Whereas the new political authorities focused on economic development and modernisation and strengthening the regime, cultural and spiritual issues initially received less attention. We see these matters addressed, however, in the visual arts. Not only in Kazakhstan, but also in other former Soviet republics, a new national identity needed to be imagined. Kazakhstani artists centred their attention on developing a new identity for the newly established country (Sorokina and Shklyayeva 2016, p. 3). Although the aesthetic and philosophical preferences of individual artists, as well as newly emerging art collectives (such as Kyzyl Tractor), differed, they all could draw on a common cultural and religious heritage. What is more, the artists have become cultural trendsetters with the opportunity to speak openly and without prejudice about burning social, cultural and political issues through their work. Art was not limited in scope, and a new environment for creativity began to emerge, which was freer from censorship and stereotypes, 'official art' and 'moral attitudes'. Creative associations such as Green Triangle (Zelenyi Treugol'nik), 
Night Tram (Nochnoi Tramvai), Red Tractor (Kyzyl Traktor) and non-formal groups of artists demonstrated the trend of 'free art' and its popularisation (cf. Kudaibergenova 2019). Below, we will focus on the art collective Kyzyl Tractor and its reimagining of nomadic steppe culture and its vernacular religion.

In the early 1990s, Kyzyl Tractor was established by Vitaliy Simakov. It was to become 'Kazakhstan's most celebrated art collective'2. The members-Said Atabekov, Smail Bayaliev, Moldakul Narymbetov, Arystanbek Shalbayev and Vitaliy Simakov-decided to set themselves the task of 'returning to the lost roots' of nomadic culture (Chukhovich 2011). As Kudaibergenova (2018, p. 436) notes, 'Focusing on such discourses as nomadism, shamanism, the land and the steppe that were previously considered "backward", "uncivilized" and certainly unwelcomed by the Soviet cultural frameworks, the new generation of postsocialist cultural producers attempted to bare these contradictions.' She continues: 'To them, shamans and nomads were in no way backward but rather authentic and real in comparison with the rigid and hegemonic perspective of the Soviet literary and artistic canons of Socialist Realism' (Kudaibergenova 2018, p. 436). Kudaibergenova uses the term Punk Shamanism (coined by Kazakh artist Almagul Menlibayeva) for the new wave of post-Soviet cultural production. It resisted the propagandistic discourse on national identity and looked for decolonised 'self-representation' by drawing on the cultural and spiritual resources of what used to be the lived religion of the nomads on the steppe. Simultaneously, these artists wanted their art to be of societal relevance. They not only sought to dismantle the Soviet legacy, but also addressed the encroaching globalisation, offering a critique of capitalism, and they were wary of 'self-Orientalizing' practices from a cosmopolitan standpoint (Kudaibergenova 2019, p. 230; Kudaibergenova 2018, 2019). The theme of nomadism fit with the increased globalisation due to the hegemony of neoliberalism in the 1990s and especially with cosmopolitanism in the international art world. Locally, however, the exploration of nomad culture by Kyzyl Tractor was not readily accepted by other Kazakhstani artists and was considered rather primitive, as came to the fore during a meeting dedicated to the memory of Moldakul Narymbetov that took place in December $2019^{3}$. It must be noted that nomadic religious life was far from being dogmatic or rigid and mainly concerned ritual practices related to Shamanism, Tengrism and Sufism (see further below). The Kyzyl Tractor art collective staged (imagined) shamanic rituals as performance art.

The group's name is derived from a memorial tractor from the Soviet era installed on a pedestal at the South Kazakhstan Regional Museum of History and Local Lore in Shymkent (Figure 1). Smail Belyaev, a member of the art group, describes the way in which the name was selected as follows:

We started to be exhibited, and our expositions were utterly different. In Shymkent our works could be seen in the gallery of modern art, which appeared in the beginning of the 90s in the Regional Museum of History and Local Lore. Once preparing the next exposition, we stood at the entrance to the museum while thinking about the name of the exhibition. A couple of meters away from us was established a red coloured tractor on the pedestal - a monument of industrialization of the 30s. And then Moldakul Narymbetov said: "What to think here? Let it be "Kyzyl Tractor". We agreed. Soon this name was assigned to our entire group. (Galushko 2018)

The red tractor at the time was associated with avant-garde labour enthusiasm. Vitaliy Simakov explains the choice of the name Red Tractor (Kyzyl Tractor):

As a generation of the Soviet period, we grew up with the red colour. And no matter how politically reformed the situation is, it will remain a tractor's footprint in the field. The parents of our group members come from villages (aul in Kazakh). Red is a strong and meaningful colour without politics (Vitaliy Simakov, personal communication, 18 March 2021). 
Simakov thus links the name of the art collective he established to the experiences of a previous generation on the land. Said Atabekov also relates the tractor to working the land, but he adds that the red tractor of the monument dates back to the 1920s and 1930s, when an avant-garde in the artworld made inroads:

Before the Red Tractor art group was founded, we did an exhibition in Almaty"Shymkent trans-avant-garde"-it's like a continuation of the avant-garde tradition of the 20-30s. And the Tractor came from that era as well. Red Tractor is the machine that was used on the field in the South by ploughing, turning, sowing our land (Said Atabekov, personal communication, 18 March 2021).

According to Yerebakan (2018), Kyzyl Tractor, the art collective, 'adopted their name, which means red tractor, to signal mobility and departure from preceding cultural or artistic limitations.'

In 1990, the Kyzyl Tractor collective covered up the machine, the red tractor on the pedestal, in a performance called 'Mummification' (Figure 2). The gesture entailed an artistic appropriation, expressed by the group's name of Red Tractor, reminiscent of the well-known work of contemporary artist Christo (Christo Vladimiroff Javacheff) who used to wrap landmarks in fabrics. The performance's title suggests that by means of a symbolic plastering and bandaging of the red tractor, this model of technical progress was to be preserved for centuries.

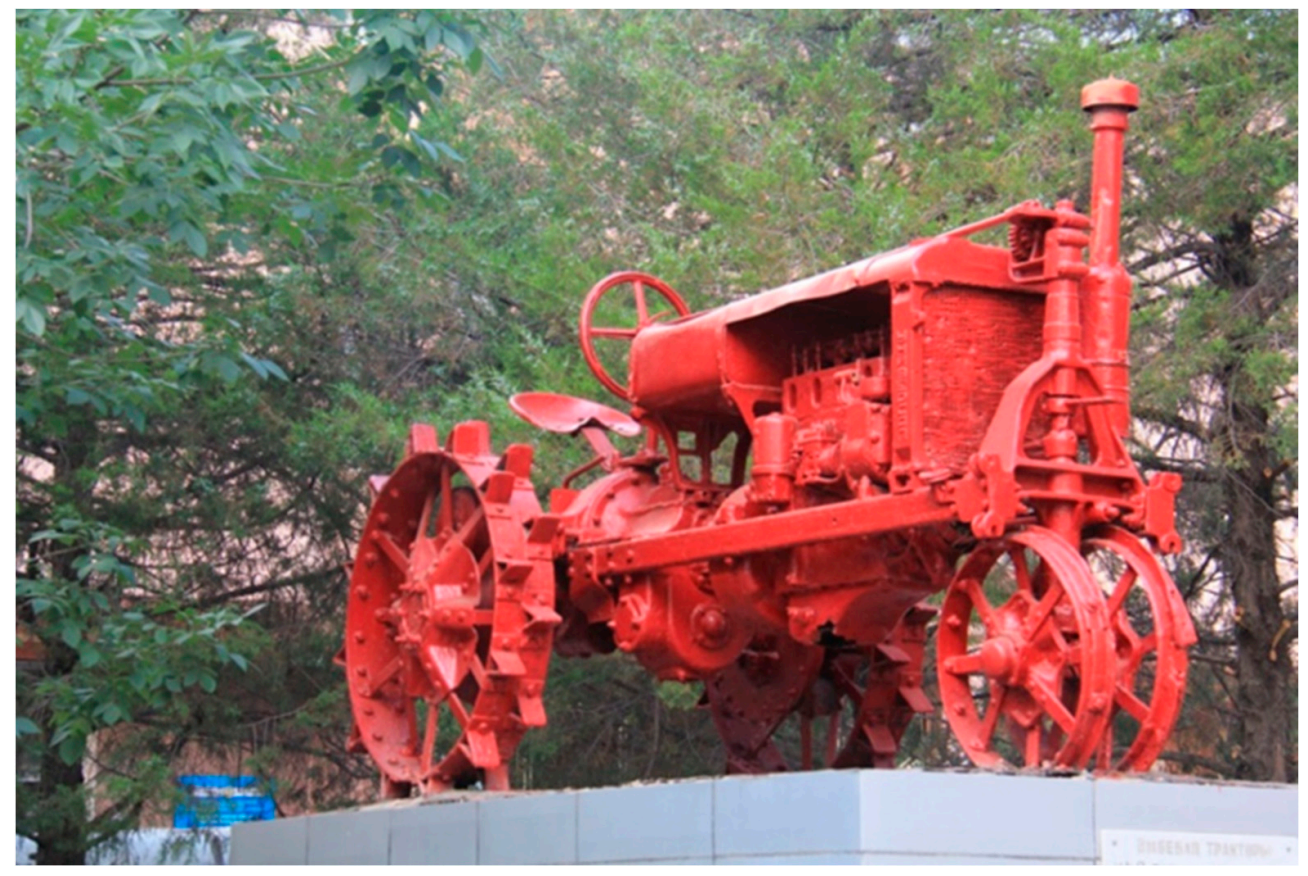

Figure 1. The Red Tractor monument on a pedestal at the South Kazakhstan Regional Museum of History and Local Lore in Shymkent. Image courtesy of Vitaliy Simakov.

As mentioned in the Introduction, Said Atabekov and the other members of the Kyzyl Tractor art collective imagined themselves as 'ancient shamans'. They wanted, as Atabekov put it, 'to reconnect with the steppe' (Kudaibergenova 2019, p. 233). This 'steppe culture' (Harva 1938, p. 16) was based on a nomadic way of life. Tengrism, an animistic religion named after a deity of the sky, Tengri (Harva 1938, p. 142), reflected the worldview and ethos of the nomads (cf. Orynbekov 2013, p. 24; Ayupov 2012, p. 13). The world in these understandings consisted of three layers: Upper (celestial), Middle (earth) and Lower (subterranean); shamans acted as intermediaries between them (Orynbekov 2013, pp. 25-26). Laruelle (2007, p. 204) describes Tengrism as the 'syncretic religion practiced in the Turkic khaganate before the peoples of the region converted to Buddhism to Manichaeism, or to Islam'. Valikhanov (1987, p. 299) speaks of syncretism as well; the Kazakhs were influenced by different religions but, 
in actual practice, maintained adherence to Tengrism and Shamanism as well. Yemelianova (2014, p. 287) makes clear that their 'nomadism, which did not allow for mosque-based worship, accounted for the wide diffusion among them of Sufism (mystical Islam).' The popular form of Sufism was spread by wandering dervishes and merchants, resulting in a 'blending of shamanism and Islam' (Mélikoff 1996, pp. 133-34). This syncretic 'islamised shamanism' took hold in Kazakhstan (and exists, to a certain extent, in the present day). 'The outer appearance of the wandering dervish', writes Mélikoff (1996, p. 134), 'was no different from that of the shaman'. Furthermore, they conduct similar ceremonies, 'intended to induce a trance', in both cases 'for healing purposes' (ibidem). We will see in Section 3 (see also Figures 5 and 6) that Said Atabekov adopted the role of dervish shaman in some of his performative art. With the other members of Kyzyl Tractor, he also performed as a shaman (baksy).

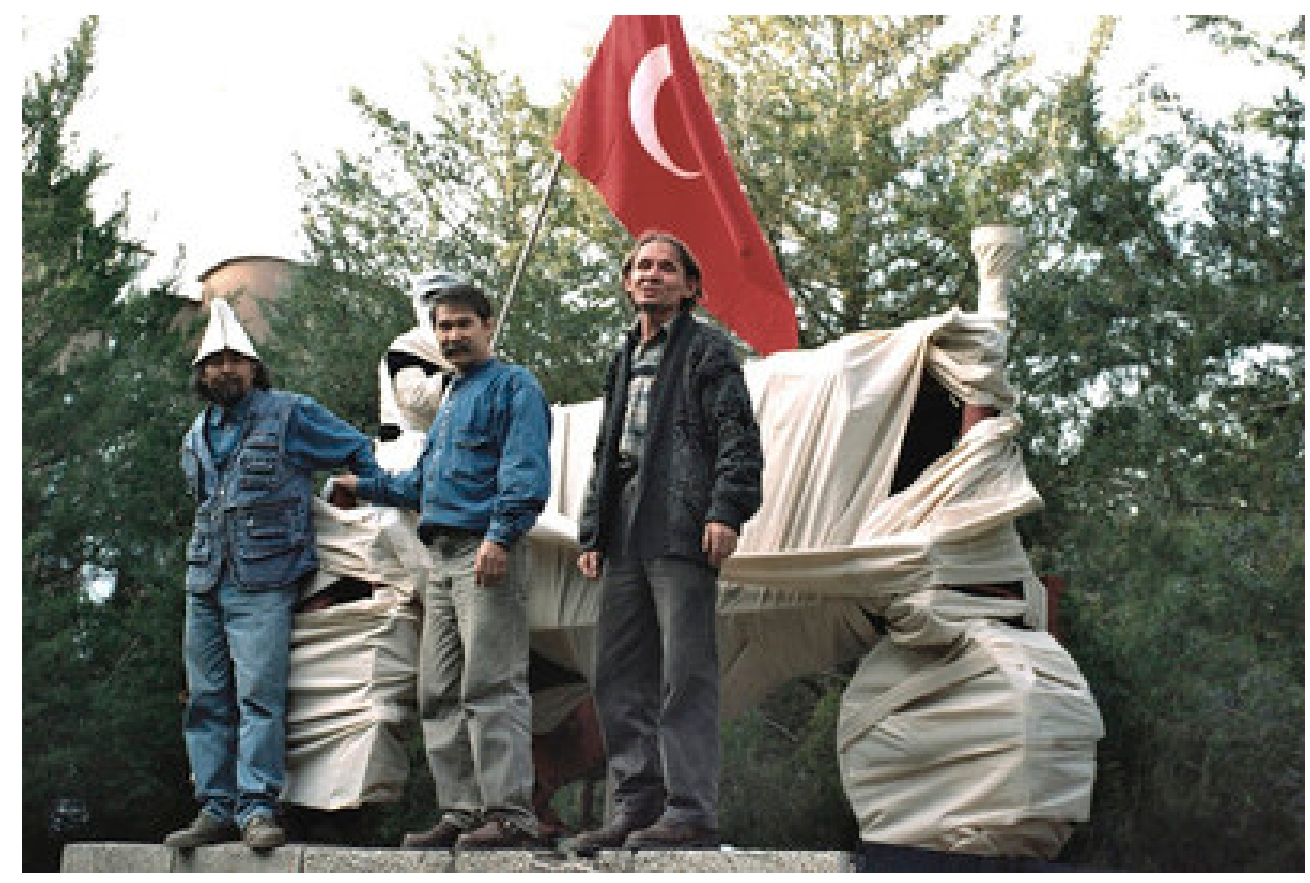

Figure 2. The performance Mummification by the Kyzyl Tractor (Red Tractor) art collective. Source: http:/ / www.shymkent13.ru (accessed on 18 March 2021).

The avant-garde art collective is known for these performances. Within the scope of this article, we have to confine ourselves to discussing just a few examples (for others, see https://www.qazart.com/kyzyl-tractor; accessed on 18 March 2021). Above, we referred to a spiritual trip the collective made dressed up as shamans and their rolling of oil barrels down Almaty's central boulevard in shamanic attire. One of the most successful performances launched by Kyzyl Tractor took place in Almaty in 1997. In the State Museum of A. Kasteev, the exhibition 'Zone of Art' was held. Due to stereotypes that lingered on, such as shamanism being considered too primitive and backward to be associated with a temple of high art, the artists in their shamanic robes and dervish costumes were refused entry to the art museum. In response, the art group members started to perform with handmade tambourines and drums right on the street, limiting their art zone to a vast territory in front of the museum. On other occasions, they also danced as shamans to the sound of traditional Kazakh instruments, such as dombra, kobyz, tambourine and drums (cf. Kendirbaeva 1994; Adams 2020, p. 174), handcrafted from leather, felt, wood and other natural materials.

A recent highlight was a large-scale survey exhibition dedicated to Kyzyl Tractor in the art centre Mana Contemporary in Jersey City, New Jersey, USA. In this 2018 exhibition, 'Collections of Thoughts: Inventing Stories', the collective showcased its artwork of the 
previous decades. What is more, preceding the opening, four members, including Said Atabekov and Vitaliy Simakov, restaged the 2003 performance 'Purification'. Kyzyl Tractor's work was recommended 'for reorienting nomadic, Sufi and Shamanistic philosophies as new artistic language ${ }^{4}$. The spectacular performance heightened that impression. In her review, Wong (2018) writes that 'Purification is a cleansing ritual that celebrates Shamanistic customs while also self-consciously presenting them in a post-modern context.'

Here, we draw on the description of the performance by Wong (2018) and Kopzhasarova (2018). A large shaman's drum was placed on the pavement in front of the cultural centre Mana Contemporary (Figure 3). The drum, three meters tall when put on its side, was made of wood and leather. To emphasise the object's naturalness and primitive crudeness, the artists did not stretch the skin smoothly and neatly but rather attached it to the wooden frame with tears and rough edges. One artist-shaman beat the drum with a stick as he pushed and wheeled it onto the pavement. Another one, dressed as a dervish, pulled a stack of what appeared to be prayer rugs on a rope. Meanwhile a third artist-shaman with a bucket of water made libations, the ritual gesture of pouring water as an offering. He threw it in the air, and coming down, the water splashed all over the concrete. The performers also started to burn adraspan grass (Peganum harmala or wild rue), filling the air with smoke for the sake of ritual cleansing. They were running around and screaming. The crowd of onlookers moved aside. The large drum was rolled around the corner (Figure 3). Next, the performers entered the building with it, followed by the audience. Inside the galleries, the procession halted. The drum was laid flat, and one of the artists climbed on top (Figure 4). He leafed through the felt 'book' (the stack of rugs), sprinkling it with water and shaking out the dust (Wong 2018; Kopzhasarova 2018). The performance left an impression on the audience.

Vitaliy Simakov, the troupe's leader, remembers that a Kazakh woman approached them during the performance. She asked them to fumigate her and her son with adraspan. It is still common practice in her country of origin, following the tradition of the shamans, to burn adraspan as a purifying and protective measure. Likewise, Kazakhs visit the graves of the dead, burn adraspan and pray to the souls of the dead (aruahs); the continued practice of ancestor worship, a custom in contradiction to Islamic dogma, underscores the syncretic nature of religiosity among the Kazakhs. The American audience experienced the performance by Kyzyl Tractor in a different way. In the words of Vitaliy Simakov:

For the Americans, it was a shock. With great curiosity they filmed the demonstration, clapped, shouted, and thanked. Then they came up and said: "it's as if you awakened us, we are a technical civilization, and you gave us the opportunity to feel what is practically strangled-smells and rhythms of nature, primitive magic, human nature". (Kopzhasarova 2018)

Following Gell (1992), the artists of Kyzyl Tractor employed a 'technology of enchantment'. Their performance with its shamanic ritual gestures and paraphernalia enchanted the audience. The spectators were drawn in due to the virtuosity with which the ritual process was carried out. The artists-cum-shamans created a kind of magic in their handling of the massive drum. In the process, they turned the observers into participants who experienced something out of the ordinary. This is reminiscent of the role of shamans as mediators (Orynbekov 2013, pp. 25-26). The shaman is regarded as 'a master of spirits', assuming 'a special social position' and using recognised 'methods and paraphernalia' (Shirokogoroff 1935, p. 274). As mentioned, a shaman is an innovator and integrator, who is of societal relevance with regard to meaning making.

Siikala and Ulyashev (2016, p. 176) consider the shaman 'a problem-solver', 'the best adviser in the crises caused by spirits and a functionary of common rituals even today.' For Kudaibergenova (2019, p. 234), the shamanic performances of Kyzyl Tractor serve to make people reflect on the spiritual void and meaninglessness of the present and disenchanted world, 'calling for alternative religious practices in Central Asia and beyond to be remembered and considered and for spiritual pluralism to be ensured.' The artists, however, are also well aware of romanticised understandings of shamanism. These are 
extensively discussed in Znamenski's 2007 book, The Beauty of the Primitive: Shamanism in the Western Imagination. It came also to the fore in the response of the American audience to the shamanistic performance, which they termed 'primitive magic'. In an essay entitled 'The shaman reenacted', Parisi (2017) draws attention to this awareness: 'In the past interpreted as an almost ethnographic attempt to rediscover their roots, the work of Kyzyl Traktor instead seems to poke fun at the orientalist stereotypes through which westerners often view Central Asia.' Irony, as we shall see, is certainly part of the work. It fits well with the liminal and ambivalent position of the shaman. Let us now turn to the individual work of Said Atabekov, who exploits the ambivalence of the dervish shaman and uses irony. A case in point is his work on the video 'Neon Paradise' (see here below, Figure 6), which not only demonstrates a technology of enchantment, but also the enchantment of technology (cf. Gell 1992).

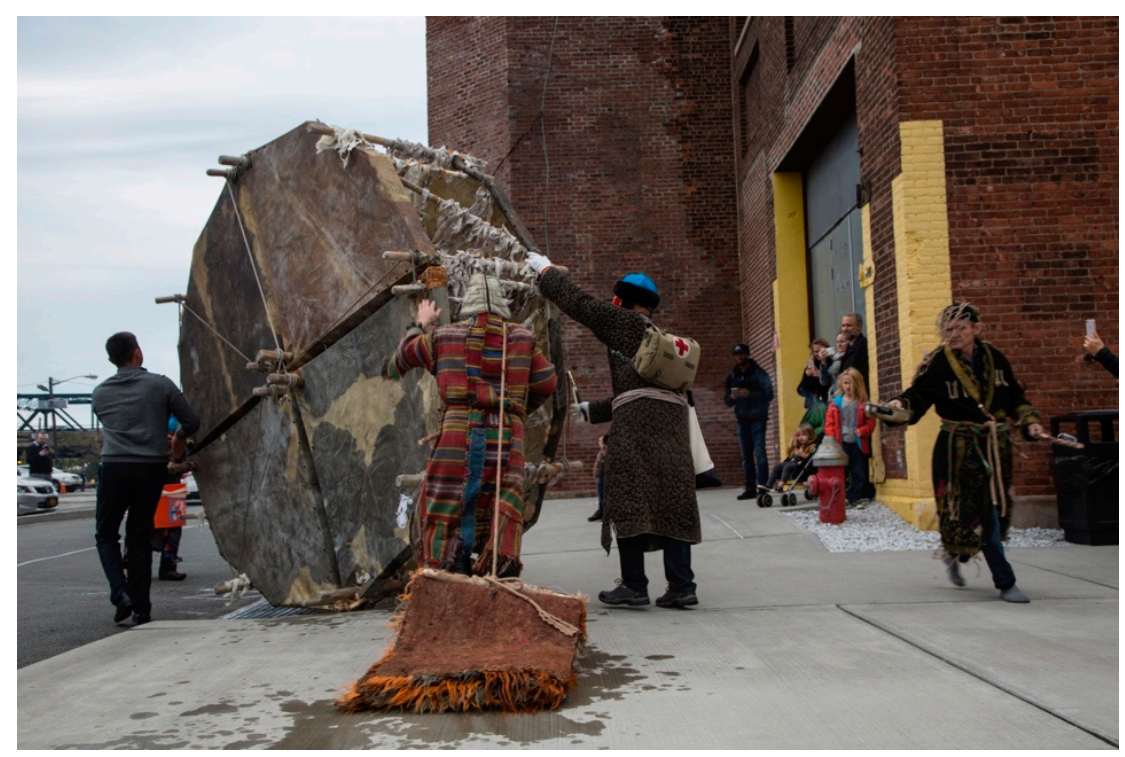

Figure 3. The enlarged shaman's drum on the pavement in front of Mana Contemporary in New Jersey City, USA, during the performance 'Purification'. Image courtesy of Said Atabekov.

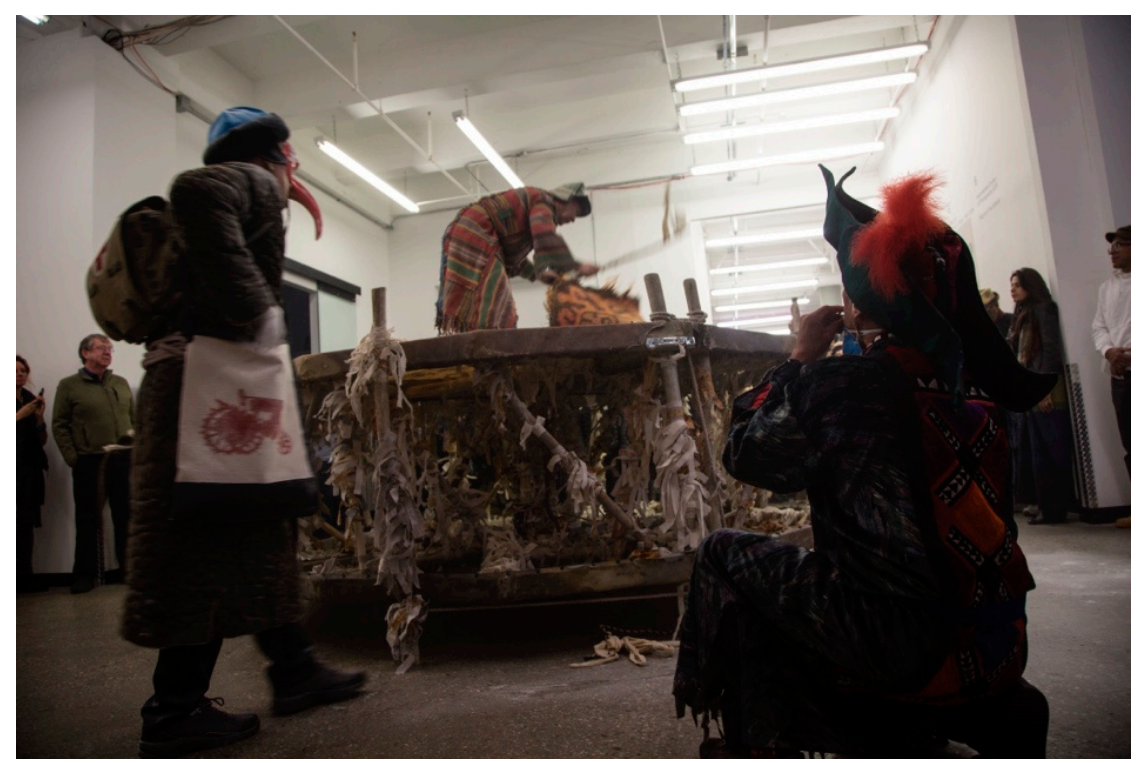

Figure 4. Members of Kyzyl Tractor in shamanic attire performing a ritual cleansing with an oversized shaman's drum indoors in the galleries of Mana Contemporary in New Jersey City, USA. Image courtesy of Said Atabekov. 


\section{Said Atabekov as a Dervish Shaman Betwixt and between Nostalgia and Modernity}

Activities with the art collective Kyzyl Tractor have made up a fair part of Said Atabekov's career as an artist. However, Atabekov has also managed to pursue a successful individual career as an artist independent of the collective. He is one of Central Asia's foremost artists whose work, spanning a variety of media, has been exhibited at many leading international art venues.

Said Atabekov was born in a village in the Tashkent region in Uzbekistan in 1965. He now lives and works in Shymkent, Kazakhstan. While most Kazakh artists prefer to live in cities such as Almaty (also called the cultural capital), Nur-Sultan (the capital) or even abroad, Atabekov deliberately chooses to live in Shymkent. The large and modern city in southern Kazakhstan is located in a region that has preserved its cultural heritage to a greater extent than the other regions.

Atabekov can be seen as part of the generation of Kazakh artists who witnessed the significant and rapid cultural and political changes surrounding the collapse of the Soviet Union. As with all Kazakh artists of his generation, the theme of the search for a new identity was expressed in his art. In addition to the decline of communist ideology, his personal experience was also an important reason for that search. In Uzbekistan, he was repeatedly made aware of his ethnicity. Being a Kazakh, he felt like an outsider, someone who did not really belong there, despite the fact that he was born and raised in Uzbekistan.

That is why he always wanted to move to Kazakhstan, which he did in the 1980s when he enrolled at the Kasteev College of Art and Design in Shymkent. Atabekov graduated in 1993, the year of his first solo exhibition, 'I is not We', which demonstrated that he was able to go beyond 'the Soviet aesthetic of collectivism' ${ }^{5}$. At the same time, as we have seen, he created art and performed as a member of the Kyzyl Tractor collective. In an artistic sense, we contend that he made this ambiguity productive, in that it thematised the tension between the individual and the collective. He took the role of a dervish shaman, who stands out from the crowd but who also fulfils a societal function as a healer and in crisis resolution. The wandering dervish-cum-shaman, in addition, refers to nomadism and mobility. The shaman (baksy) and wandering dervish are indistinguishable in their outlook and performance (Mélikoff 1996, p. 134), but they have a background in, respectively, Tengrism, the animistic religion of the steppe, and Sufism, that is, mystical Islam. The dervish arrived later on the scene than the shaman, but during the time of Genghis Khan, who adhered to Tengrism but was religiously tolerant, a blending seems to have taken place. Both pre-Islamic shamanism and ancestor worship were embraced by Islam in nomadic Central Asia (Kaynar and Zakhitzhanova 2016). Unlike the scriptural Islam of neighbouring, sedentary Tajiks and Uzbeks, the nomadic Kazakhs practiced a vernacular Islam (Yemelianova 2014, pp. 287-88). Asceticism and wandering were of particular spiritual significance to the dervishes. Similar to the cattle-breeding nomads, they were on the move in the Kazakh steppe. With their representations of (syncretic) shamans, Said Atabekov and other members of Kyzyl Tractor delved into cultural and religious heritage, reimagining the past to offer an alternative model for the place of religion and meaning making in society (Kudaibergenova 2018, 2019). As Kudaibergenova (2019, p. 232) puts it, the 'theme of religious pluralism and complex interpretations of religion guided and influenced a large part of Atabekov's work and performances.' In mythopoetic performances and photomedia art, this contemporary artist provides food for thought about identity.

Atabekov not only engages with the past and nostalgia for life on the steppe, but also reflects on the belief in progress and modernity. He does so by traversing the boundaries between past and present and steppe and urban life. Kudaibergenova (2019, p. 238) notes that 'the steppe is constantly on the move in all Atabekov's works: it can be transformed and placed in the urban landscape and still make sense there.' As in shamanic flight or as a nomad, the artist is moving from one world to the other. He places himself as a dervish shaman in front of automatic sliding doors to a city shopping centre, and in other works, he deals with the encroachment of global consumerism and the invasion of doctrinal religion 
in the imaginary steppe. These are representative works from Atabekov's oeuvre that we will discuss in the remainder of this article. These concern a dervish shaman, the nomadic game of kokpar and the advent of rigid religion, respectively.

Between the mid-1990s and mid-2000s the dervish figured in works such as 'The Dream of Genghis Khan (1998) (Figure 5), 'The Neon Paradise (2004) (Figure 6) and 'Noah's Ark' (2004). In the black and white photo 'Prayer Rug (The Dream of Genghis Khan-2)' (Figure 5), Atabekov is portrayed as a dervish shaman with a conical hat, sitting at a 'prayer rug' (namazlyk) formed by a 'carpet' of stones. The stones are reminiscent of graves in the steppe and seem to refer to ancestor worship. Simultaneously, it seems to embody the dervish's recitation in the last phase of zikirshi: 'the place I sit is my grave, the clothes I put on are my shroud, the breath I have taken is the last of my breaths' (Muminov 2018, p. 291). The syncretic nature of the image is further underscored by the runic writings in the ancient Türkic language in the background. The sepia colour historicizes the photograph, making it look old, similar to a photograph by a late-nineteenth-century ethnographer of shamanism.

During his performance in the Vienna Festival in the 1990s, Atabekov knelt on the carpet made of stone and fell to the floor while his colleagues circled his figure with green paint. Art historian Ibraeva (2014) interprets the mention of Genghis Khan in the title of Atabekov's work as a reference to Joseph Stalin, for both historical rulers created an empire, characterised by a strong centralised power and ideology in uniting the peoples of a vast territory. In both cases, this led to migration flows, which radically changed the ethno-cultural situation in the region and contributed to the formation of a multinational population. Atabekov uses historical figures and elements of nomadic culture not only to reflect on the quest for identity, issues of multiculturalism and religious syncretism, but also the history and traditions of the Kazakhs. (Under Stalin, by the way, people in Kazakhstan still relied on the persecuted shamans as healers (Kindler 2018, p. 36)). The portrayed person in Figure 5 is not only a dervish and shaman rolled into one here, but also a single Kazakh representing the Kazakh nation in general.

In the video project 'Neon Paradise (2004) (Figure 6), Said Atabekov sits in the robes of a shaman in front of automatic sliding doors that open every time he prostrates and prays. The automatism in the dutiful prayer of a Muslim is thus mirrored by the sliding doors. The prayer, as suggests the title of this work, gives access to a paradise. The paradise here, however, is the neon-lit shopping centre with all of its opulence and decadence. 'Neon Paradise' provides a powerful cultural and religious critique: Be careful what you wish for. It entails a number of symbolic inversions (cf. Babcock 1978): firstly, that a shaman performs the prayer, when Islamists obsessively prosecuted shamans because of the latter's religious ideas (Tengrism, perceived as polytheism). The shaman (baksy) turns the tables as he puts the veneration of the true God into question by directing the prayer to the warehouse of earthly riches. Secondly, whereas a shaman employs a 'technology of enchantment' in her or his practice, the performance in front of the automatic sliding doors boils down to an 'enchantment of technology' (in terms of Gell (1992)). Thirdly, the shaman relates to nomadism and being in touch with nature by means of the animistic religion of Tengrism, but rather than the blue skies of the infinite steppe, there is now artificial neon light and a permanent construction that can be seen as a triumph of sedentarisation. Finally, the powers of the shaman (read: tradition) have become futile in the face of modernity.

Atabekov himself describes this work as humorous and ironic. According to his recollection, shopping centres with automatic sliding doors installed first came into being in the 1990s. His son got scared when he went to the doors and they opened. It was a great discovery for him and something comparable to a fairy tale: magic in real life. Atabekov himself experienced a similar shock in Warsaw back in 1988, when he first saw an automatic door system in one of the shopping centres in the inner city. Then, for Said Atabekov, the shopping centre seemed Paradise 6 . The artist uses the background sound of pop music to his video artwork 'Neon Paradise', as Sorokina (2016, p. 247) observes, and 
he 'captures the video several times over from a computer screen in order to obtain a trash quality, which suggests the antiquity and timelessness of the narration.'

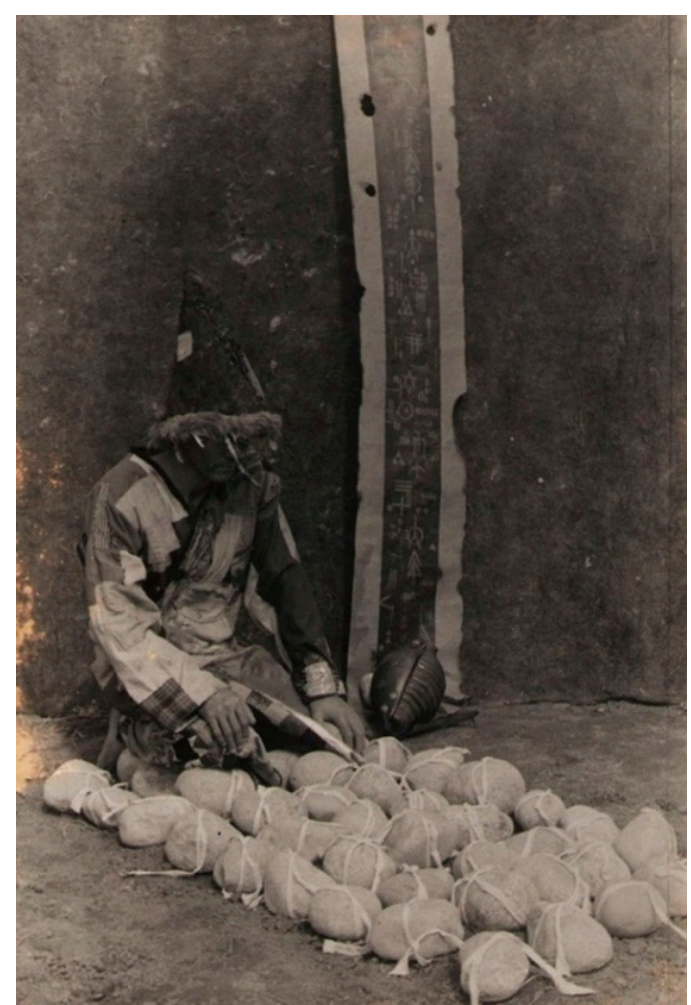

Figure 5. Said Atabekov, Prayer Rug, 1998, from the series The Dream of Genghis Khan-2. Image courtesy of Aspan Gallery, Almaty.

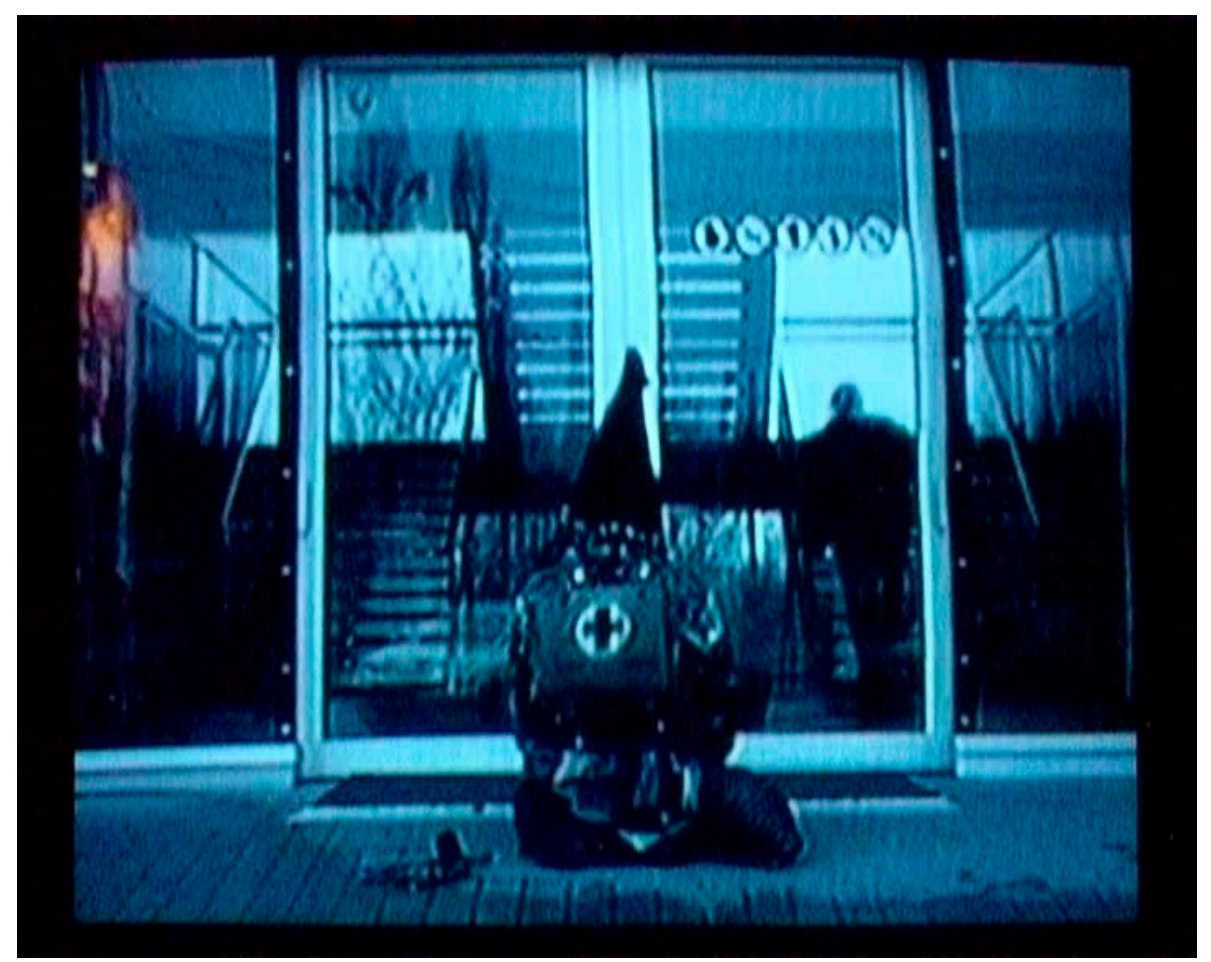

Figure 6. Said Atabekov. Screenshot from the single-channel video Neon Paradise, 2004. Image courtesy of Aspan Gallery, Almaty 
In 2017, it became the title work of the exhibition 'Neon Paradise: Shamanism from Central Asia' in Laura Bulian Gallery in Milan, Italy. Valentina Parisi (2017) writes in her accompanying essay about Atabekov's 'ironic deconstructive stance' that is rooted in his performances with the Kyzyl Tractor collective. In her view, 'Atabekov's reenacted shaman is first and foremost a čudak, an "eccentric" uprooted from his village community context, where he performs bizarre rites that have been inevitably contaminated by the penetrating force of Western culture' (Parisi 2017). Therefore, in the videographed performance 'Neon Paradise', the artist-shaman before automatic doors is 'interacting, alas, no longer with the spirits, but rather with a humble photocell' (ibidem). According to Yuliya Sorokina, who curated Kyzyl Tractor's contribution to the 52nd Venice Bienale, this work by Atabekov on video can be seen as 'teleshamanism' (Fomenko 2013).

One of the anonymous reviewers of this article raised the issue of cultural appropriation in view of 'Atabekov's representation and self-representation as shaman', an adherent of Tengrism and/or dervish. The reviewer asks: 'Does being of Kazakh nationality automatically permit Atabekov to take on these identities?' Moreover, 'whose interests do his new artistic forms and representations serve?' We will come back to these questions below.

Thackara (2017) notes that 'while artists from the West who are working with this subject matter may face charges of cultural appropriation, artists from countries where forms of shamanism are practiced also show the influence of this heritage in their work.' Said Atabekov and his fellow artists from the Kyzyl Tractor collective are a case in point. Because the artists live and work in an urban setting, Parisi (2017) agrees that 'the issue of appropriating a shamanic otherness - which coincides with an ancestral identity for artists from Central Asia-remains open.' What complicates the matter is that shamans in the post-Soviet era do operate in urban settings. Humphrey (1999) made a study of Buryat shamans in the Siberian city of Ulan-Ude. She found that they are in demand to the extent 'that villagers now often invite city shamans to revivify spirit relations' (Humphrey 1999, p. 9). In Kazakhstan, Almaty-based art writer and curator Yuliya Sorokina considers Said Atabekov a 'real shaman'; he is a genuine shaman, she adds, because 'you can feel it when you start talking to him' (Fomenko 2013). Moreover, Parisi (2017) senses that something is going on, because she writes: 'For Said Atabekov the encounter with the myth of the shaman takes on the features of personal experience with alienating consequences.' This resonates with the idea of the shaman as a wounded healer (see Merchant 2012). Atabekov told Atanova (2020), 'I am trying to find myself in my works, impersonality has no value to me.' Freed from the artistic and religious repression of the Soviet era, Atabekov and his fellow artists of the Kyzyl Tractor collective seek to explore and shed light on their cultural heritage.

The collapse of the Soviet Union made the quest for identity acute. Moreover, the project of identity formation could not be left to the new state of Kazakhstan. The nonstate-sponsored artists operated within the framework of the international, cosmopolitan art world (Kudaibergenova 2018). 'For some art critics and theorists, artists are seen as heirs of indigenous shamans', Mayer (2008, p. 85) reminds us. What was at stake for Atabekov, however, was to regain a connection with the steppe and its way of life. In this endeavour, the artist was all but naïve. More than other members of the Kyzyl Tractor art collective, Atabekov is known for his 'critical discourse', which is also conveyed in his works of art (Sorokina 2016, p. 247). As we have seen with their performances as shamans, the collective tried to dismantle Soviet as well as Western stereotypes. Their shamanic performances might be conceived of as experimental cultural history, exploring possibilities (cf. Davis 2003) in search of cultural and spiritual resources in nomadic, lived religion going beyond the colonial perspectives, state propaganda and Western clichés (Kudaibergenova 2018, 2019). In his individual works, Atabekov has also used the figure of the dervish shaman to reflect on aspects of contemporary society. In his creativity, he is very much akin to a shaman. Coming back to the issue of cultural appropriation, Parisi (2017) phrases an important question: 'To what extent can contemporary artists 
transform the needs of shamanic practice and re-elaborate them within their own artistic strategy?'

Following Gell (1998), this would depend on the agency of Atabekov's works of art and oeuvre. His art has found a receptive audience internationally, and this might create feedback locally. What is for sure is that Atabekov's work contributes to a more positive image of long-despised vernacular religion. Buyandelgeriyn (2007, p. 133) demonstrates that there exists a deep mistrust of present-day shamans in Ulan-Ude, Mongolia, due to historical oppression disrupting the practice and the introduction of the market economy leading to the suspicion of a loss and lack of knowledge and new shamans going into it for the money. Atabekov cleverly uses the figure of the shaman in his art to critique the past dismissal of vernacular religion and present ideology of capitalism and development. He has every right to perform as a shaman because there is no authority other than the calling of the spirits that could forbid him from doing so. Speaking of cultural appropriation is difficult, in addition, because the concept of shamanism is ill-defined (Vitebsky 2000; Lindquist 2005). Furthermore, it is virtually impossible, as Znamenski (2007, p. 290) puts it, 'to freeze religions and cultures in time and space'. Shamanic revival is influenced by neo-shamanism and Western style, and shamans from various parts of the world are increasingly interconnected (Johnson 1995; Vitebsky 2000; Lindquist 2005; Znamenski 2007). Given the globalisation of shamanism, it is not surprising that Atabekov's performative and photomedia art has wide appeal.

\section{Battling for Space: Ancient Nomadic Tradition and Global Consumerism}

Dave (2007, p. 23) asks, 'If the Kazakhs had few material and literary artefacts, and if the nomadic oral tradition and memory were virtually eradicated under Soviet rule, then what kind of a "national" past and history of the Kazakhs as a nation can be said to exist?" Horses are emblematic of nomadic culture. A game on horseback of grabbing the carcass of a goat, called kokpar, which is popular across Central Asia, has been singled out as a marker of national identity in Kazakhstan (Boast 2017). Said Atabekov became fascinated by the competitive sport. He filmed the kokpar game in black and white from a helicopter for the series of works 'Battle for the Square' (2013) and 'Steppen Wolves' (2014).

Part of his fascination stems from Atabekov's desire to escape cramped housing, dating from Soviet times, and a sedentary way of life. In his own words: 'It is hard for me to live in the city. I can't stop thinking about going to the steppe, to the open space' (Atanova 2020). Atabekov's appreciation for the culture and religion of the nomads should also be mentioned. The latter 'believed in the harmonious unity between humans and the surrounding world, the blue skies and endless steppe, and in particular, the helping power of ancestral spirits and the cult of saints and batyrs (military chieftains)' (Yemelianova 2014, p. 287). With regard to the game of the horsemen, aiming to capture and throw a headless goat into the cauldron (a ring-shaped earthen rampart serving as a goal), Atabekov was interested in the battle.

'Shot from above, the fragmented close-ups of the battle remind us of great military battles and legendary heroes from an unknown epic and unknown history', according to Sorokina (2016, pp. 247-48). The artist mostly shows the work on four screens, and each screen displays the game in a different season. In this way, Atabekov tries to achieve a sense of 'tangibility' and endless action using a panorama presentation, so the viewers become part of the mass of riders (Figures 7 and 8 ) involved in the process of dividing the carcass of a goat as a piece of land. According to Atabekov, on a more global scale, this project is about 'the market competition, the capture of air and water spaces, high prices per square meter of housing' (Novikova 2016). The horsemen who stomp on the spot and fight over the goat's carcass stand for the modern Kazakh man who is searching for his place and somehow for his identity. On a personal level, Atabekov also attributed meaning to the battle. During the creation of this art project, the artist's family namely lived in a one-room apartment, where each family member fought for one's square meter. He extrapolated that to society by saying, 'The game itself embodies the image of our modern world, which is 
governed by fierce competition' (Atanova 2020). Furthermore, for Atabekov, the game 'is just like a religion, where people pray to God before the start, asking for the blessings ${ }^{7}$.

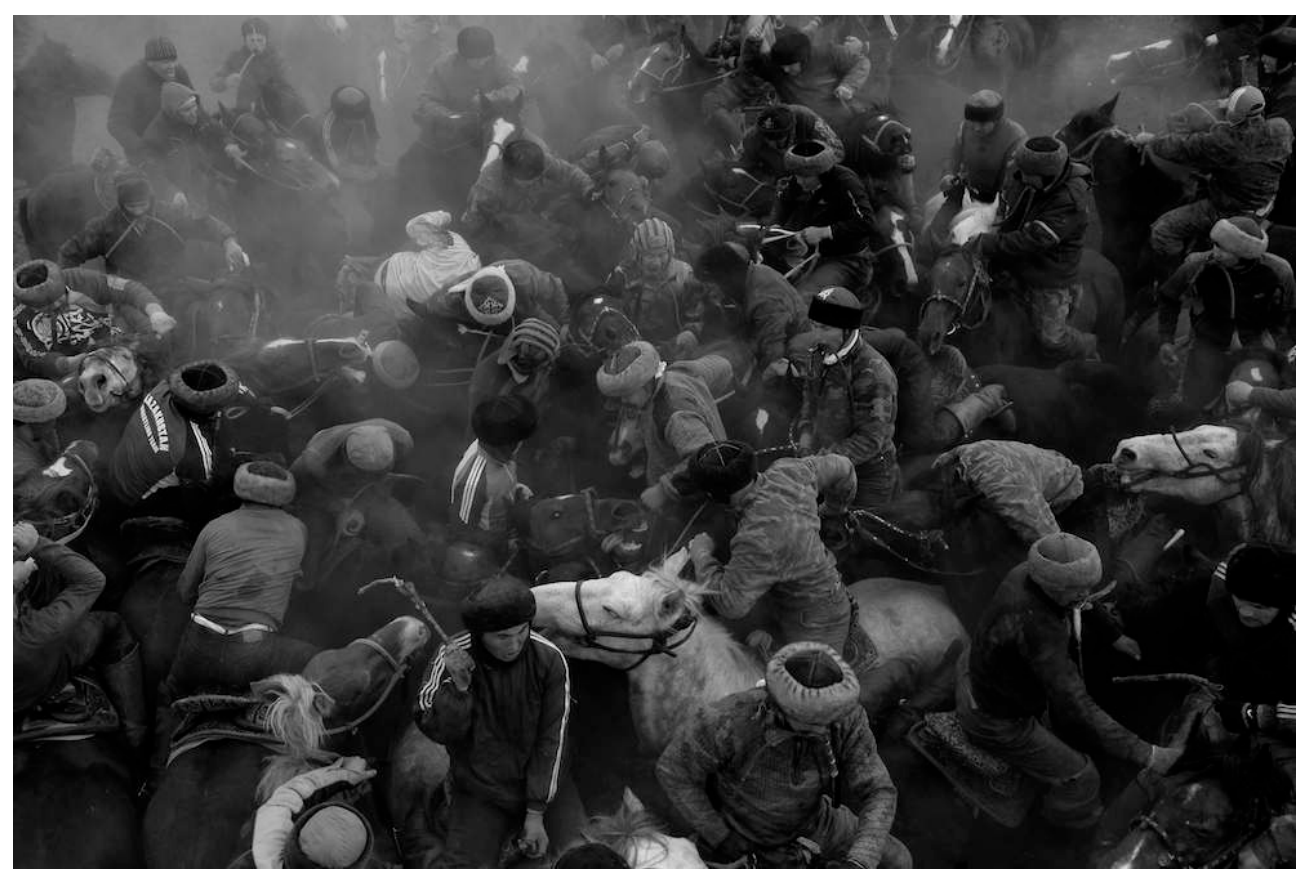

Figure 7. Said Atabekov, Battle for the Square, 2013. Image courtesy of Aspan Gallery, Almaty.

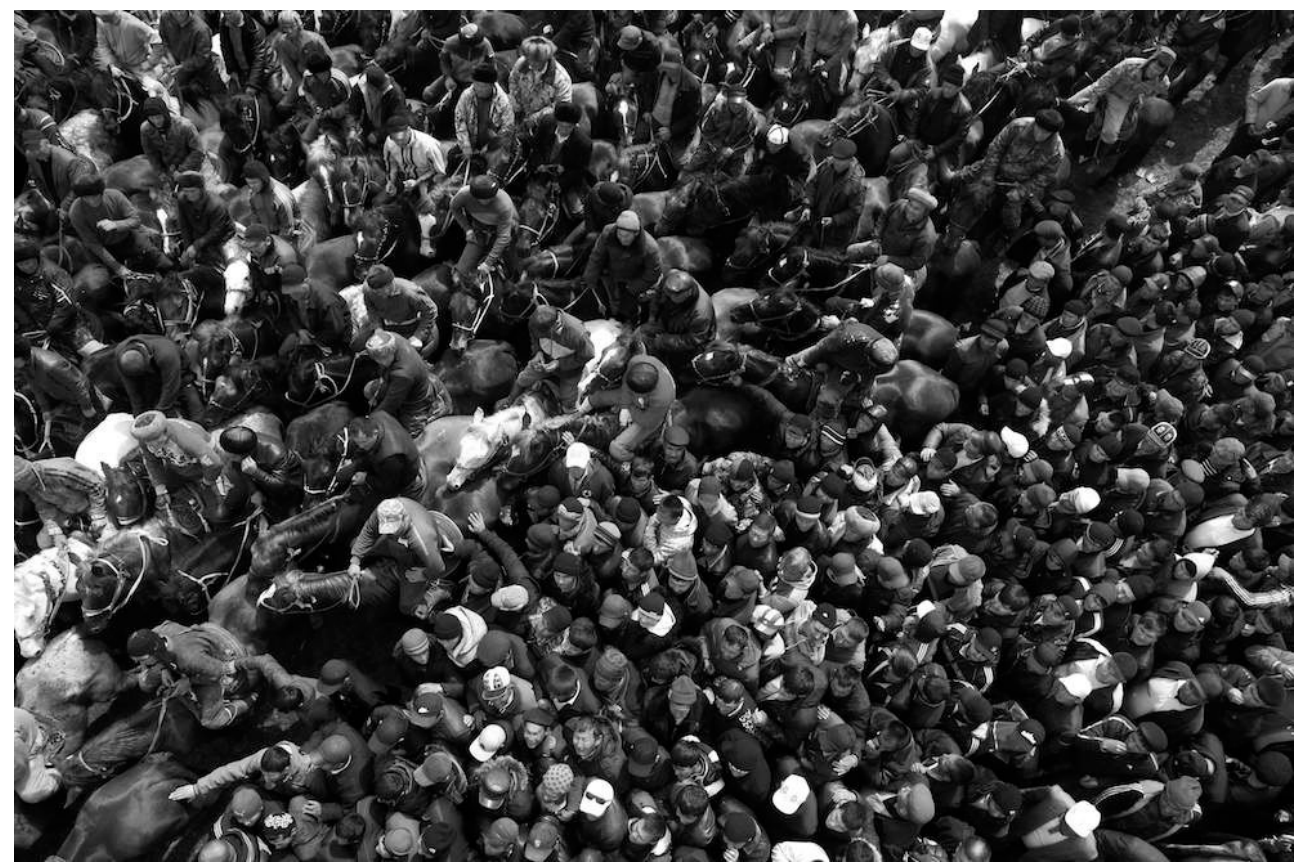

Figure 8. Said Atabekov, Kokpar \#2, 2013. Image courtesy of the Aspan Gallery, Almaty.

Further pursuing the theme of kokpar, Said Atabekov presents a series of works entitled 'Steppen Wolves' (2014). These focus on the riders playing the game in order to emphasise certain aspects, such as heroes, colours and paraphernalia. Said Atabekov's photography (Figure 9) of a rider sitting on a horse with a red star on the back of his jacket and a tank helmet shows a 21st century man who is living in the era of globalisation and in a culture of consumerism. Following the globalisation of fashion, riders sew logos of famous brands with errors, such as Prada, D\&G and AirAstana, for their identification of involvement in 
a particular social group, achieving social equality or even superiority by demonstrating famous logos in their image. Artificial access to the world of high fashion, and therefore to the 'elite', gives an idea of belonging and identification with the 'premier league'. Drawing attention to the cheap, Chinese fake brands, 'Atabekov challenges both the authenticity of contemporary practice that sells itself as "traditional" but also challenges the notion of globalization of Kazakh traditions' (Kudaibergenova 2018, p. 447).

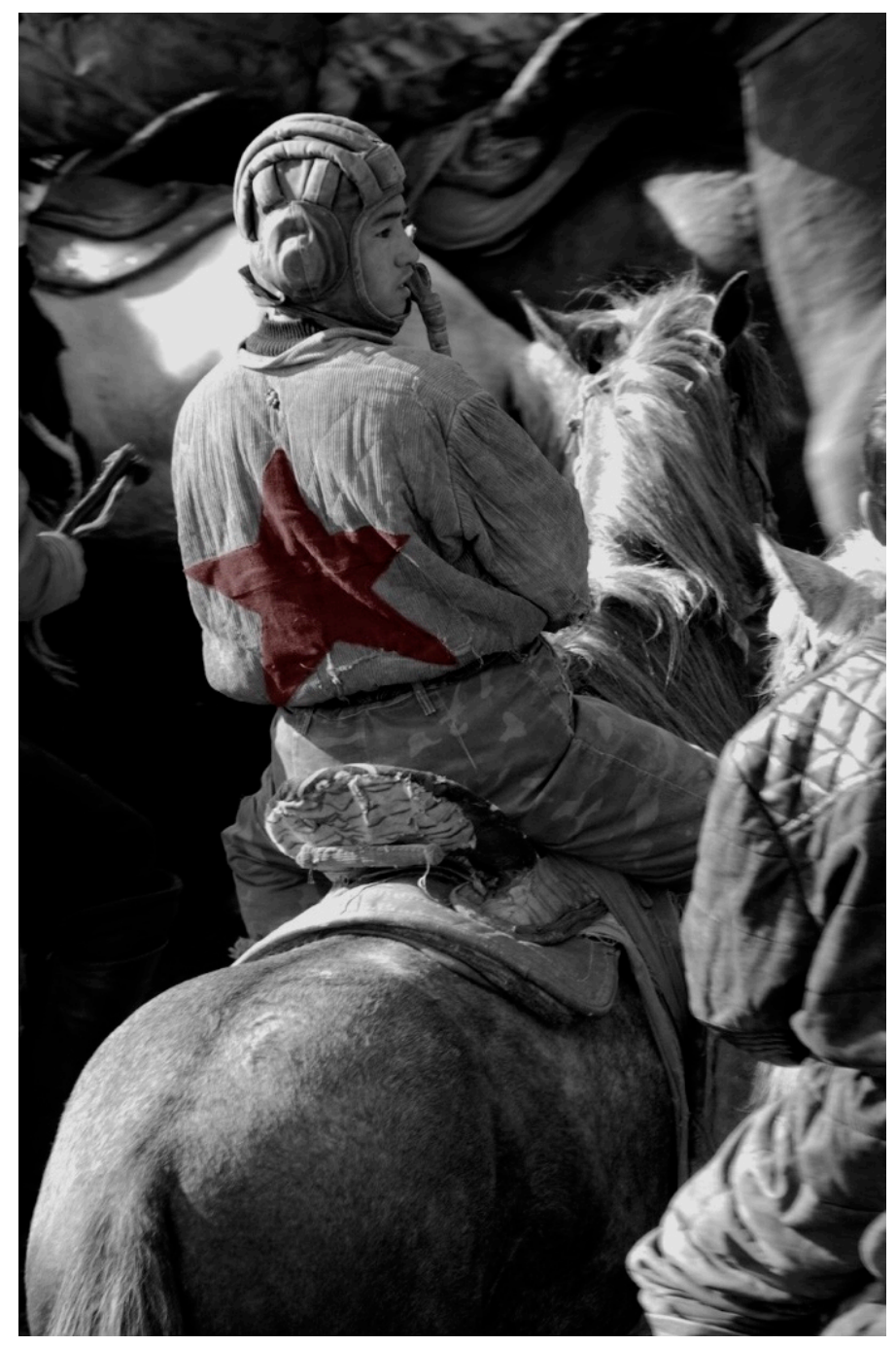

Figure 9. Said Atabekov, Steppen Wolves, 2014. Image courtesy of the Aspan Gallery, Almaty.

In an interview with a local magazine, Atabekov speaks about the beginning of this particular art project:

A few years ago, when I arrived at the kokpar, I saw a big red star on the back of one of the riders. It was clear that he sewed this huge star on his jacket. It seemed to me that he flew into our steppe from some other, distant planet. My project dedicated to kokpar began with this horseman and his star. Now, this rider with a star on his back has become not only a steppe wolf but also a part of the contemporary art world. Now he is a superstar. (Nusimbekov 2016)

In December 2020, Atabekov held a video art workshop ${ }^{8}$. During the workshop, he revealed that he was thinking about continuing the kokpar-themed project. Only this time, he did not want to show what happened from the outside, but from the point of view of the goat's cadaver. He would attach a camera to it and film the whole game process. 
However, Atabekov immediately added that the idea was difficult to put into practice for technical reasons.

Following our discussion of the figure of the dervish shaman and the nomadic game of kokpar in Said Atabekov's oeuvre, let us now turn to the theme of the advent of rigid religion.

\section{From Tolerant Syncretism to Rigid Religion}

Kazakhstan saw a religious revival when the Soviet Union, with its state ideology of secularism and atheism, collapsed. Notwithstanding that the Republic of Kazakhstan is formally a secular state and no confessional political parties are allowed, the authorities have not refrained from making use of the spiritual potential of religion in government programmes to promote national identity (Yerekesheva 2020; Sharipova 2020). Initially, the attention was focused on the pre-Soviet past, especially the heritage of nomadic steppe culture and religion. Nomadism could not be combined with 'mosque-based worship' (Yemelianova 2014, p. 287). 'The nomads had syncretically incorporated some Islamic practices, especially pertaining to life-cycle rituals with other shamanic, animistic rituals and cults of deities (tengriianstvo)' (Dave 2007, p. 186n38). In contrast to the oppression of religion in the Soviet era, independent Kazakhstan's leadership vouched for 'people to profess and practice their respective religions' freely (Malik 2019, p. 66). Islam has been a key factor in defining post-Soviet identity in Central Asia (Gunn 2003); it is now by far the largest religion in Kazakhstan. In the last decade of the twentieth century, the number of registered mosques increased from 40 to 2300 (Yemelianova 2014, p. 290). Yet, most Kazakhstani Muslims adhere to vernacular Islam. Survey data from 2012 reveal that only four percent perform the daily prayers, and not more than ten percent go to mosque every week (Schwab 2015, p. 52). However, the government has privileged scriptural Islam over the indigenous, traditional and vernacular version willy-nilly (Yemelianova 2014; Malik 2019). Yemelianova (2014, pp. 286-87, 294-95) attributes this to the ignorance of the authorities trained in Soviet times and the influence of the youngest generation (the qur'anists) within the political establishment who have embraced Salafi Islam.

Responding to the question of the place and role of religion in modern Kazakhstan, Atabekov created the project 'The Way to Rome' (2007-2015). Working on this art project, he was inspired by the Great Silk Road and Marco Polo's journey in the thirteenth century from Italy through Central Asia to China. As the title 'The way to Rome' suggests, Atabekov imagines the trajectory in a westward direction, reversing Marco Polo's path. The Abrahamic religions used to be foreign to the Central Asian region where the inhabitants adhered to Tengrism. Figure 10 is Atabekov's photograph of three iron signs with the symbols of the three monotheistic religions-Judaism, Christianity and Islam, respectivelyplaced in a field of poppies. The poppies in the steppe, along with the religious symbols, evoke Karl Marx's statement that religion is 'opium for the people' (the crescent with handle, ironically, resembles the sickle, symbol of the peasants in the Soviet era, which might refer to the enforced collectivisation and sedentarisation). Atabekov uses the steppe (including its open sky, so important in Tengrism) as a backdrop to this work in which it serves as a reminder of the inclusiveness of the worldview of the nomads (Kudaibergenova 2019, p. 238). As mentioned, aspects of the syncretic religiosity of the Kazakhs, such as ancestor worship, have survived until today. 


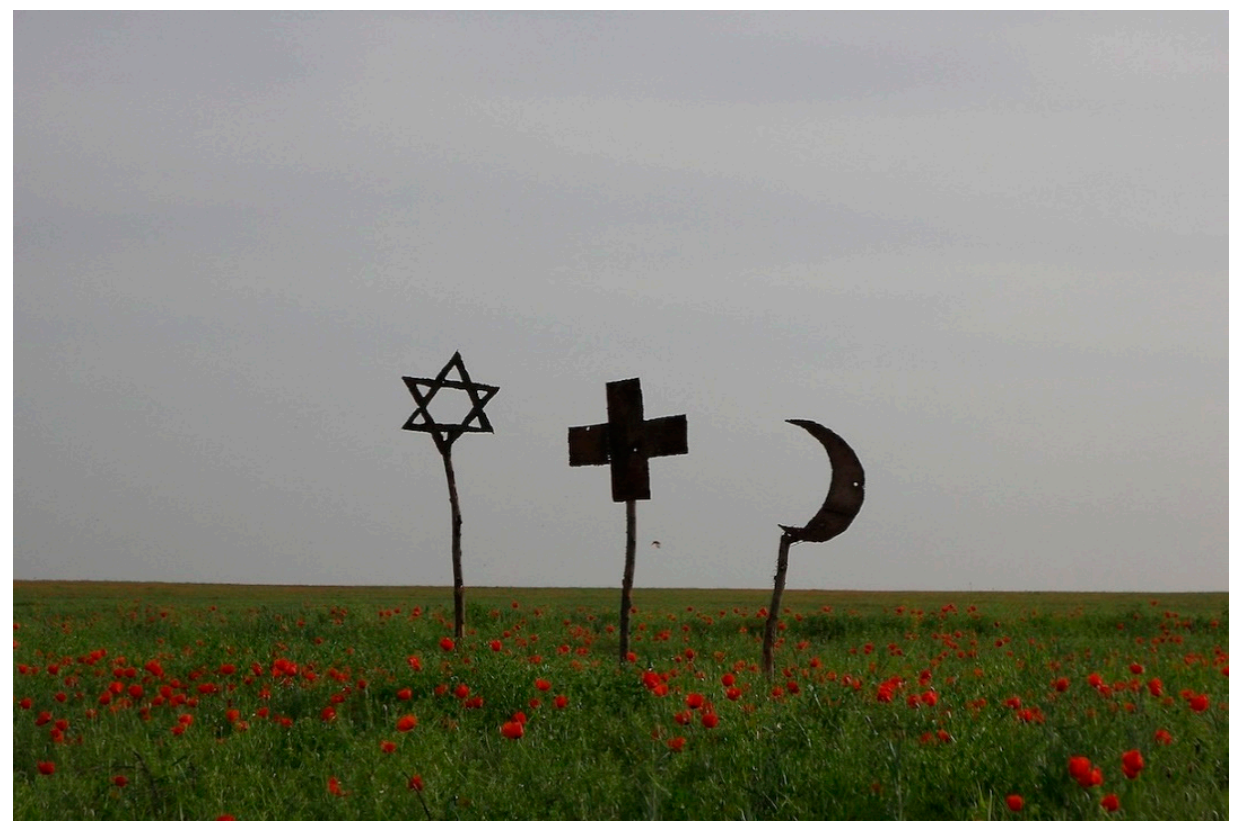

Figure 10. Said Atabekov, The Way to Rome, 2007-2015. Image courtesy of the Aspan Gallery, Almaty

In Figure 11, Atabekov portrays a man who is carrying a crescent-shaped object as a burden on his shoulder. He walks through the steppe. His shadow shows the sun light the 'moon', carried in full daylight. The work is part of the series 'The Way to Rome'. The man carrying the (sacred) object on his shoulder is reminiscent of the iconic image of Jesus Christ carrying his cross. It also signals that a hegemonic, monotheistic religion has made inroads in the steppe, in this case, scriptural Islam. Atabekov seems to suggest that the descendants of the steppe people carry this type of Islam as their cross in contrast to the syncretic and informal, mystical Islam of the dervishes.

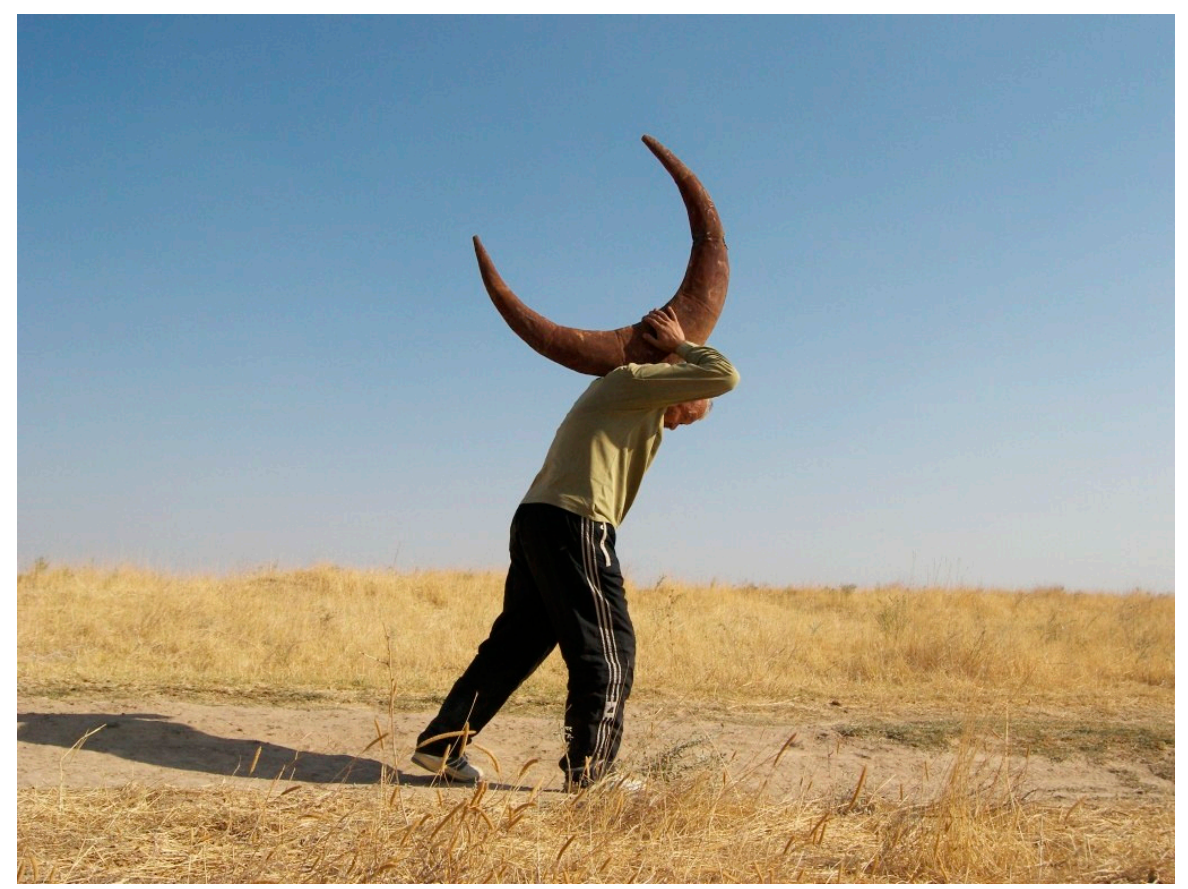

Figure 11. Said Atabekov, The Way to Rome, 2007-2015. Image courtesy of the Aspan Gallery, Almaty.

In his video project 'Bosphorus Prayer' (2007), Atabekov brings Islam and Christianity into dialogue (Figure 12). He creates a new, syncretic ritual of prayer, combining elements 
from the religious practice of both Christianity and Islam. A woman performs this 'fundamental ritual' (Mauss [1909] 2003, p. 24). With the gestures of her hands in motion, she makes a cross, which refers to Christianity; however, the way she holds her hands is characteristic for Muslims when they pray (Figure 12). 'Bosphorus Prayer', with the non-verbal language of prayer, was part of the works from four of Atabekov's projects shown at the 54th Venice Biennale in 2011. The exhibition in the Central Asian Pavilion had the telling title of 'Lingua Franca'. By means of the 'Bosphorus Prayer', Muslims and Christians can be seen as reconciled in their worshipping.

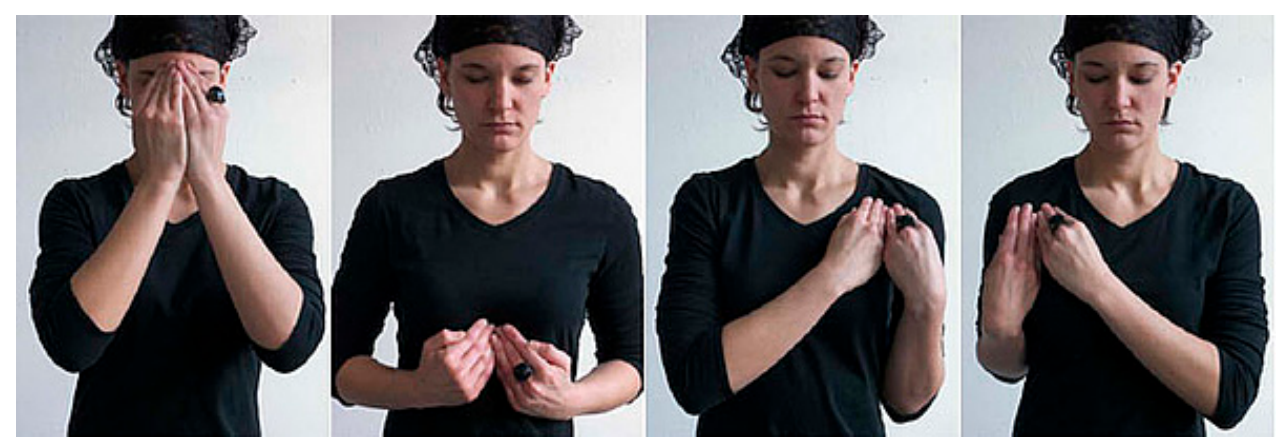

Figure 12. Said Atabekov, Bosphorus Prayer, 2007. Source: https:/ / universes.art/en/nafas/articles / 2011/said-atabekov/photos / 02-bosphorus-prayer (accessed on 18 March 2021).

In Atabekov's oeuvre, however, we see that religion not only unites but also divides. His 2019 art project 'Zhusan' (Figure 13) deals with militant Islam. Zhusan is the Kazakh word for "bitter wormwood", which has been a revered plant of the Great Steppe since ancient times, a sacred element of traditional Kazakh culture. In his artwork 'Zhusan' (Figure 13), Atabekov covers a horse saddle with military camouflage clothing and the symbols of Islam. In an interview, he offered the following comment on this work: 'toy for children, and pillow for adults ${ }^{9}$. Since time immemorial, Kazakhs have been raising cattle and using the horse as their primary mode of transport. Therefore, horse equipment, with the saddle as the most important item, held a special place in Kazakh life. The saddle was not only an object of material value but was also treated as something of sacred significance. The lack of a saddle in the house was considered a shame (Tokhtabaeva 2017, p. 15).

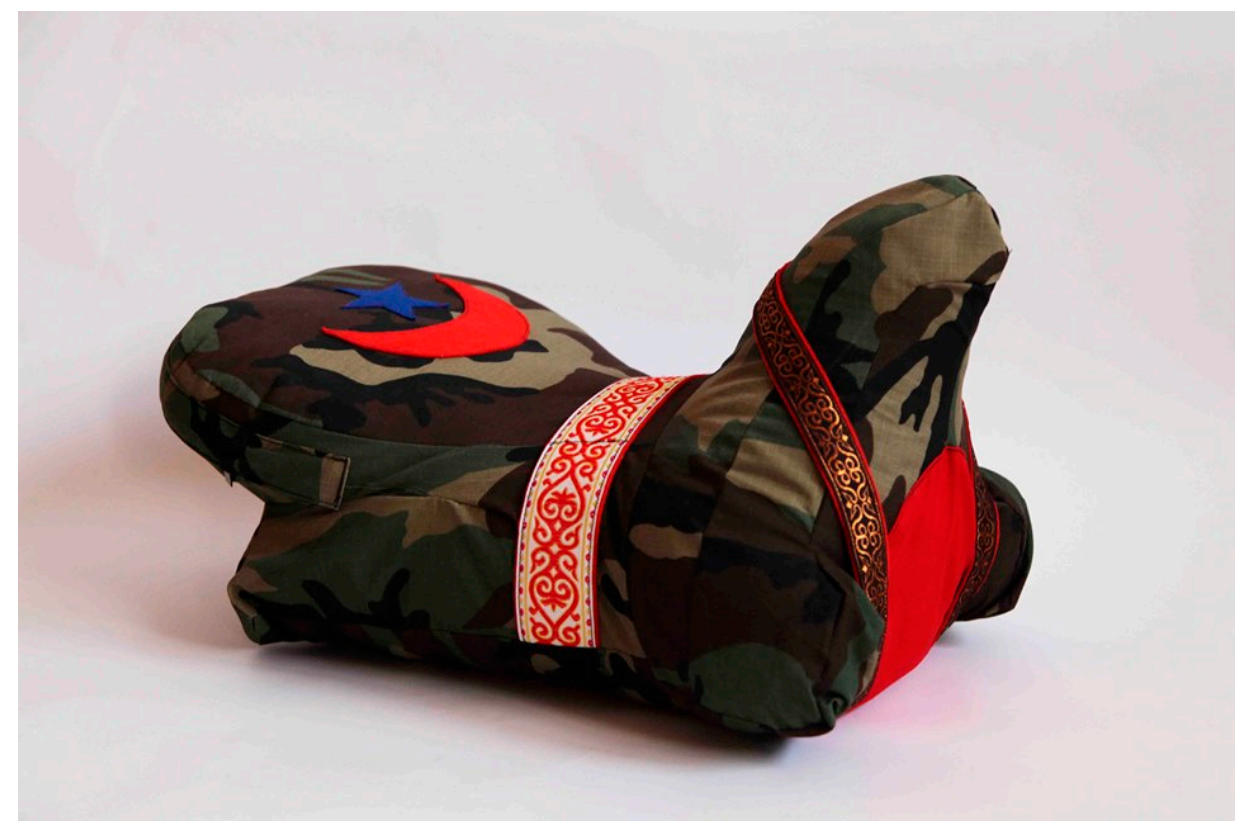

Figure 13. Said Atabekov, Zhusan, 2019. Image courtesy of Said Atabekov. 
The saddle refers to the nomadic warriors (batyrs) of the past. With the object's cover, however, the artist puts Islamic fighters in the saddle, as it were. The Islamic fighters substitute for the nomadic warriors. The saddle and its cover-up link the art project to the earlier kokpar project (discussed in Section 4): the 'Steppen Wolves' turned into soldiers who go to war in the Middle East. In the Zhusan project, Atabekov reflects on the problem of the growth and spread of religious radicalism and extremism in society in Kazakhstan as well as Kazakhstani joining the ranks of the Islamic State and other terrorist groups in the Middle East. His remark that the saddle art object serves as 'a toy for children' and 'pillow for adults' has to be seen in light of the governmental project 'Zhusan'. This is the name for the repatriation missions, bringing back hundreds of children, a smaller number of women and some men to Kazakhstan, in spite of the potential threat to national security (Dronzina 2021). The saddle displays the underlaying tension and ambivalence and bears testimony to tolerant, vernacular religion being overwritten by a rigid, scriptural one.

\section{Conclusions}

Said Atabekov is one of Central Asia's foremost artists for good reason. In this article, his engagement with religion in his artwork over the course of his career is central. He became an artist when Soviet repression of art and religion ended. The new and independent Republic of Kazakhstan faced the task of identity formation and nation building. Together with other members of the art collective Kyzyl Tractor, Atabekov enacted the role of a shaman and tried to reconnect with the imaginary steppe and its nomadic culture and inclusivist, syncretic religion of the pre-Soviet era. With their performances as shamans, the collective tried to dismantle Soviet as well as Western stereotypes. Their shamanic performances might be conceived of as experimental cultural history, exploring possibilities in search of cultural and spiritual resources in nomadic, lived religion going beyond the colonial perspectives, state propaganda and Western clichés. Atabekov's work contributes to a more positive image of long-despised vernacular religion. In his individual works, he has also used the figure of the dervish shaman to reflect on aspects of contemporary society. The same accounts for his works on the game of kokpar and the advent of rigid religion. His thought-provoking art raises important questions about the globalisation of capitalist consumer culture (and its competitiveness) and of fundamentalist, scriptural Islam, while being situated in a globalised framework of cosmopolitan art.

Author Contributions: Conceptualization, E.Y.; literature search, E.Y. and E.V.; interviews, E.Y.; writing—original draft preparation, E.Y.; writing—review and editing, E.Y. and E.V.; visualization, E.Y.; supervision, E.V. All authors have read and agreed to the published version of the manuscript.

Funding: This research received no external funding.

Acknowledgments: We thank Said Atabekov for agreeing to participate in an interview with the first author, for his subsequent assistance during the course of our writing of this article and for his generously given permission to reproduce the images of his works; we thank Aspan Gallery (a contemporary art gallery in Almaty, Kazakhstan) for allowing us to use Said Atabekov's images from their website http: / / aspangallery.com/en (accessed 18 March 2021). We are also grateful to Vitaliy Simakov and Said Atabekov for providing us with information on the naming of the art collective Red Tractor (Kyzyl Tractor). We thank the two anonymous reviewers for their helpful comments, which made this a much better article than it otherwise would have been.

Conflicts of Interest: The authors declare no conflict of interest.

\section{Notes}

1 Interview of Said Abatekov by the first author, January 2020.

2 https://www.qazart.com/kyzyl-tractor (accessed 19 March 2021).

3 Moldakul Narymbetov (passed in 2012) is considered to be one of the brightest representatives, inspirers and leaders of the Kyzyl Tractor group, as well as the founder of the performance genre in Kazakhstan.

4 https://artradarjournal.com/2018/10/23/thinking-collections-telling-tales-focus-kazakhstan-part-ii-in-jersey-city / (accessed 19 March 2021). 
5 See https:/ / www.auroomart.com/en/artists/said-atabekov (accessed 19 March 2021).

6 Said Atabekov, interview with the first author, July 2020.

7 Said Atabekov, interview with the first author, July 2020; see for the horse as a symbol of national identity in Kazakhstan also Sarbassova (2015).

8 On 14-15 December 2020, Said Atabekov held a video art workshop on the Zoom platform as part of the School of Artistic Gesture project. The first author of the article took part in this workshop.

9 Said Atabekov, interview with the first author, July 2020.

\section{References}

Adams, Margrethe. 2020. Steppe Dreams: Time, Mediation and Postsocialist Celebrations in Kazakhstan. Pittsburgh: University of Pittsburgh Press.

Atanova, Snejana. 2020. Genghis Khan, Kok-par and other stories of the Great Steppe by Said Atabekov. Contemporary Art. November 3. Available online: https://voicesoncentralasia.org/genghis-khan-kok-par-and-other-stories-of-the-great-steppe-by-saidatabekov/ (accessed on 25 December 2020).

Ayupov, Nurmagambed. 2012. Тенгрианство какоткрытое мировоззрение: Монография[Tengrism as an open worldview: Monography]. Almaty: "KIE" Publisher.

Babcock, Barbara A. 1978. Introduction. In The Reversible World: Symbolic Inversion in Art and Society. Edited by Barbara A. Babcock. Athica: Cornell University Press, pp. 13-36.

Balikci, Asen. 1963. Shamanistic behavior among the Netsilik Eskimos. Southwestern Journal of Anthropology 19: 380-96. [CrossRef]

Boast, Will. 2017. I'll get my goat: Kazakhstan's ancient sport for modern times. The Guardian. August 15. Available online: https:// www.theguardian.com/world/2017/aug/15/kokpar-kazakhstan-ancient-sport-for-modern-times (accessed on 19 March 2021).

Bowie, Fiona. 2006. The Anthropology of Religion: An Introduction, 2nd ed. Oxford: Blackwell.

Buyandelgeriyn, Manduhai. 2007. Dealing with uncertainty: Shamans, marginal capitalism, and the remaking of history in postsocialist Mongolia. American Ethnologist 34: 127-47. [CrossRef]

Cameron, Sarah. 2018. The Hungry Steppe: Famine, Violence and the Making of Soviet Kazakhstan. Ithaca: Cornell University Press.

Chukhovich, Boris. 2011. Mixed language: Said Atabekov. Themes and contexts of his four projects at the Central Asian Pavilion, Venice Biennale 2011. Available online: https:/ / universes.art/en/nafas/articles/2011/said-atabekov (accessed on 20 April 2020).

Dave, Bhavna. 2007. Kazakhstan: Ethnicity, Language and Power. London: Routledge.

Davis, Natalie Zemon. 2003. Movie or monograph? A historian's/filmmaker's perspective. The Public Historian 25: 45-48. [CrossRef]

DeWeese, Devin. 2014. Shamanization in Central Asia. Journal of the Economic and Social History of the Orient 57: 326-66. [CrossRef]

Djaltchinova-Malec, Elvira Eevr, ed. 2014. Shamanhood and Art. Budapest: Akademai Kiado, Warsaw: Polish Institute of World Art Studies.

Doyon-Bernard, Suzette. 1997. Jackson Pollock: A twentieth-century Chavín shaman. American Art 11: 8-31. [CrossRef]

Dragadze, Tamara. 1993. The domestication of religion under Soviet communism. In Socialism: Ideals, Ideologies, and Local Practice. Edited by Chris M. Hann. Abingdon: Routledge, pp. 141-50.

Dronzina, Tatyana. 2021. Kazakhstan: A nation that treats people with kindness. The Astana Times. March 23. Available online: https: / / astanatimes.com/2021/03/kazakhstan-a-nation-that-treats-people-with-kindness-and-respect/ (accessed on 26 March 2021).

Eliade, Mircea. 1989. Shamanism: Archaic Techniques of Ecstasy. Harmondsworth: Penguin. First published in 1951.

Fomenko, Andrey. 2013. Мифотворцы и радикалыю[Myth-makers and Radicals]. ART1 Visual Daily web-Site (20 October 2013). Available online: https:/ / art1.ru/2013/10/24/mifotvorcy-aktivisty-i-neprisoedinivshiesya-25461 (accessed on 12 February 2020).

Galushko, Irina. 2018. В США завершилась выставка легендарнойарт-группы«Кызыл Трактор» [The exhibition of the legendary art group "Kyzyl Tractor" has completed in the USA]. Express-K Web-Site (3 December 2018). Available online: https: / / express-k. kz/news/ekspozitsiya/v_ssha_zavershilas_vystavka_legendarnoy_art_gruppy_kyzyl_traktor-133053 (accessed on 15 May 2020).

Gell, Alfred. 1992. The technology of enchantment and the enchantment of technology. In Anthropology, Art and Aesthetics. Edited by Jeremy Coote and Anthony Shelton. Oxford: Clarendon Press, pp. 40-63.

Gell, Alfred. 1998. Art and Agency: An Anthropological Theory. Oxford: Clarendon Press.

Gunn, Jeremy. 2003. Shaping an Islamic identity: Religion, islamism, and the state in Central Asia. Sociology of Religion 64: 389-410. [CrossRef]

Handelman, Don. 1967. The development of a Washo shaman. Ethnology 6: 444-64. [CrossRef]

Harva, Uno. 1938. Die religiösen Vorstellungen der altaischen Völker. Helsinki: Suomalaien Tiedeakatemia.

Humphrey, Caroline. 1999. Shamans in the city. Anthropology Today 15: 3-10. [CrossRef]

Ibraeva, Valeria. 2014. фрагменты вышедшейограниченным тиражом книги искусствоведа Валерии Ибраевой«Искусство Казахстана. Постсоветский период» [Fragments of the Published Limited-Edition Book by Art historian Valeria Ibraeva "The Art of Kazakhstan. Post-Soviet Period"]. Aspandau Magazine web-site (2 February 2014). Available online: https: // magazine.aspandau.kz/?P=114 (accessed on 18 May 2020).

Ingels, Tamara. 2004. Jóska Soós: A shaman as artist. In Shamanism in the Interdisciplinary Context. Edited by Art Leete and R. Paul Firnhaber. Boca Raton: Brown Walker Press, pp. 149-67.

Johnson, Paul C. 1995. Shamanism from Ecuador to Chicago: A case study in New Age ritual appropriation. Religion 25: 163-78. [CrossRef] 
Kaynar, Maral, and Zada Zakhitzhanova. 2016. Pre-Islamic beliefs of Kazakhs and the spread of Islam in Kazakhstan. In Transformations in Cultural, Social and Educational Activity: Challenges towards Contemporary Europe. Edited by Agnieszka Roguska and Alicja Antas-Jaszczuk. Siedlce: Siedlce University of Natural Sciences and Humanities, pp. 111-16.

Kindler, Robert. 2018. Stalin's Nomads: Power and Famine in Kazakhstan. Pittsburgh: University of Pittsburgh Press.

Kendirbaeva, Gulnar. 1994. Folklore and folklorism in Kazakhstan. Asian Folklore Studies 53: 97-123. [CrossRef]

Kopzhasarova, Laura. 2018. Шымкентские«трактористы» порулили вАмерике[Shymkent “Tractor” Drive in America]. Kursiv Web-Site. (2 November 2018). Available online: https:/ / kursiv.kz/news/persona/2018-11/shymkentskie-traktoristy-porulili-vamerike (accessed on 5 April 2020).

Kudaibergenova, Diana T. 2019. Religion, power, and contemporary art in Central Asia: Visualizing and performing Islam. Central Asian Affairs 6: 224-52. [CrossRef]

Kudaibergenova, Diana T. 2018. Punk Shamanism, revolt and break-up of traditional linkage: The waves of cultural production in post-Soviet Kazakhstan. European Journal of Cultural Studies 21: 435-51. [CrossRef]

Laruelle, Marlene. 2006. Tengrism: In search for Central Asia's spiritual roots. Central Asia-Caucasus Analyst 8: 3-4.

Laruelle, Marlene. 2007. Religious revival, nationalism and the 'invention of tradition': Political Tengrism in Central Asia and Tatarstan. Central Asian Survey 26: 203-16. [CrossRef]

Lindquist, Galina. 2005. Healers, leaders and entrepreneurs: Shamanic revival in Southern Siberia. Culture and Religion 6: $263-85$. [CrossRef]

Malik, Bilal Ahmad. 2019. Islam in post-Soviet Kazakhstan: Experiencing the public revival of Islam through institutionalisation. Asian Journal of Middle Eastern and Islamic Studies 13: 351-69. [CrossRef]

Mauss, Marcel. 2003. On Prayer. New York: Durkheim Press/Berghahn. First published in 1909.

Mayer, Gerhard. 2008. The figure of the shaman as a modern myth: Some reflections on the attractiveness of shamanism in modern societies. The Pomgrenate 10: 70-103. [CrossRef]

Mélikoff, Irène. 1996. From God of Heaven to King of Men: Popular Islam among Turkic tribes from Cental Asia to Anatolia. Religion, State $\mathcal{E}$ Society 24: 133-38.

Merchant, John. 2012. Shamans and Analysts: New Insights on the Wounded Healer. New York: Routledge.

Milledge, Clare. 2013. The Artist-Shaman and the "Gift of Sight". Ph.D. thesis, Sydney College of the Arts, University of Sydney, Sydney, Australia.

Misiano, Viktor. 2011. Saïd Abatekov: A magical historicism. In Prince Claus Awards 2011. Edited by Fariba Derakhshani and Barbara Murray. Amsterdam: Prince Claus Fund, pp. 30-31.

Muminov, Ashirbek. 2018. Sufi groups in contemporary Kazakhstan: Competition and connections with Kazakh Islamic society. In Sufism in Central Asia: New Perspectives on Sufi Traditions, 15th-21st Centuries. Edited by Devin DeWeese and Jo-Ann Gross. Leiden: Brill, pp. 284-98.

Nauruzbayeva, Zhanara. 2011. Portraiture and proximity: 'Official' artists and the state-ization of the market in post-Soviet Kazakhstan. Ethnos 76: 375-97. [CrossRef]

Novikova, Lyudmila. 2016. СаидАтабекоы: Битва кентавров[Said Atabekov: Battle of the Centaurs]. Interior Explorer Web-Site. (28 January 2016). Available online: http:/ / www.interiorexplorer.ru/article.php?Article=647 (accessed on 12 November 2020).

Nusimbekov, Timur. 2016. Шымкентский пост-номад[Shymkent's Post-Nomad]. Vlast Internet Journal Web-Site (05 March 2016). Available online: https://vlast.kz/people_to_watch/16147-symkentskij-post-nomad.html (accessed on 28 May 2020).

Orynbekov, Mukhanmadiyar. 2013. Генезис Религиозности в Казахстане[The Genesis of Religiosity in Kazakhstan]. Almaty: IP Volkova N.A. Publisher.

Parisi, Valentina. 2017. The Shaman Reenacted. Laura Bulian Gallery. Available online: http://www.laurabuliangallery.com/assets/ cs-neon-paradise_eng.pdf (accessed on 19 March 2021).

Sarbassova, Guldana. 2015. Language and identity in Kazakh horse culture. Bilig 75: 227-48.

Schwab, Wendell. 2015. Islam, fun, and social capital in Kazakhstan. Central Asian Affairs 2: 51-70. [CrossRef]

Sharipova, Dina. 2020. Perceptions of national identity in Kazakhstan: Pride, language, and religion. The Muslim World 110: 89-106. [CrossRef]

Shirokogoroff, Sergei Mikhailovich. 1935. Psychomental Complex of the Tungus. London: Kegan Paul, Trench, Trubner \& Co.

Siikala, Anna-Leena, and Oleg Ulyashev. 2016. Hidden Rituals and Public Performances: Traditions and Belonging among Post-Soviet Khanty, Komi and Udmurts. Helsinki: Finnish Literature Society.

Sorokina, Yuliya. 2016. From evolution to growth: Central Asian video art, 1995-2015. Studies in Russian and Soviet Cinema 10: 238-60. [CrossRef]

Sorokina, Yuliya, and Svetlana Shklyayeva. 2016. The Eurasian utopia: The legacy of the nomadic modernist. Third Text 29: 511-25. [CrossRef]

Syzdykova, Zhibek Saparbekovna. 2017. Key aspects of the Kazakh religious Identity. European Journal of Science and Theology 13: 95-109.

Thackara, Tess. 2017. Why Shamanic Practices are Making a Comeback in Contemporary Art. Artsy. Available online: https: //www.artsy.net/article/artsy-editorial-shamanic-practices-making-comeback-contemporary-art (accessed on 19 March 2021).

Tlostanova, Madina. 2018. What Does It Mean to be Post-Soviet? Decolonial Art from the Ruins of the Soviet Empire. Durham: Duke University Press. 
Tokhtabaeva, Shaizada. 2017. Символика предметов традиционного быта казахов[Symbols of household items of Kazakhs' traditional way of life]. Digital Publisher: iPUB: ISBN 9786010640108.

Valikhanov, Chokan. 1987. Следы шаманства у киргизов. В Избранные произведения[The Tracks of Shamanism Among the Kirghiz]. In Selected Works. Main Editorial Board of Oriental Literature. Publisher "Nauka": p. 414.

Vitebsky, Piers. 2000. Shamanism. In Indigenous Religions: A Companion. Edited by Graham Harvey. London: Cassell, pp. 55-67.

Vuillemenot, Anne-Marie. 2013. Muslim shamans in Kazakhstan. In Shamanism and Islam: Sufism, Healing Rituals, and Spirits in the Muslim World. Edited by Thierry Zarcone and Angela Hobart. London: I.B. Tauris, pp. 59-78.

Wallach, Amei. 1991. Censorship in the Soviet Bloc. Art Journal 50: 75-83. [CrossRef]

Wallis, Robert J. 2019. Art and shamanism: From cave painting to the white cube. Religions 10: 54. [CrossRef]

Walters, Victoria. 2010. The artist as shaman: The work of Joseph Beuys and Marcus Coates. In Between Art and Anthropology. Edited by Arnd Schneider and Christopher Wright. Oxford: Berg, pp. 35-47.

Weiss, Peg. 1995. Kandinsky and Old Russia: The Artist as Ethnographer and Shaman. New Haven: Yale University Press.

Wong, Mimi. 2018. Focus Kazakhstan-Thinking Collections: Telling Tales. ArtAsiaPacific. Web Review. Available online: http: / / artasiapacific.com/Magazine/WebExclusives/FocusKazakhstanTellingTales (accessed on 19 March 2021).

Yemelianova, Galina. 2014. Islam, national identity and politics in contemporary Kazakhstan. Asian Ethnicity 15: 286-301. [CrossRef]

Yerebakan, Osman Can. 2018. Thinking collections: Telling tales. A survey exhibition of Kyzyl Tractor Art Collective. The Brooklyn Rail. November. Available online: https:/ / brooklynrail.org/2018/11/artseen/Thinking-Collections-Telling-Tales-A-SurveyExhibition-of-Kyzyl-Tractor-Art-Collective (accessed on 19 March 2021).

Yerekesheva, Laura G. 2020. Functions of religion and dynamics of nation-building in Kazakhstan and Uzbekistan. The Muslim World 110: 64-88. [CrossRef]

Znamenski, Andrei A. 2007. The Beauty of the Primitive: Shamanism and the Western Imagination. Oxford: Oxford University Press.

Znamenski, Andrei A. 2003. Shamanism in Siberia: Russian Records of Indigenous Spirituality. Dordrecht: Springer. 